\title{
Dynamic Capabilities to Achieve Corporate Sustainability: A Roadmap to Sustained Competitive Advantage
}

\author{
Nadeem Bari *(D), Ranga Chimhundu (D) and Ka-Ching Chan
}

check for updates

Citation: Bari, N.; Chimhundu, R.; Chan, K.-C. Dynamic Capabilities to Achieve Corporate Sustainability: A Roadmap to Sustained Competitive Advantage. Sustainability 2022, 14, 1531. https://doi.org/10.3390/ su14031531

Academic Editor: Luigi Aldieri

Received: 24 December 2021

Accepted: 25 January 2022

Published: 28 January 2022

Publisher's Note: MDPI stays neutral with regard to jurisdictional claims in published maps and institutional affiliations.

Copyright: (C) 2022 by the authors. Licensee MDPI, Basel, Switzerland. This article is an open access article distributed under the terms and conditions of the Creative Commons Attribution (CC BY) license (https:// creativecommons.org/licenses/by/ $4.0 /)$.

\author{
School of Business, University of Southern Queensland, Toowoomba 4350, Australia; \\ Ranga.Chimhundu@usq.edu.au (R.C.); KC.Chan@usq.edu.au (K.-C.C.) \\ * Correspondence: u1133589@umail.usq.edu.au
}

\begin{abstract}
Dynamic capabilities and sustainability practices have become the center of attention for companies globally, but there is still a debate on how organizations can successfully develop dynamic capabilities and achieve sustainability for competitive advantage. This paper discusses the outcomes of a comprehensive systematic literature review (SLR) following the PRISMA guidelines and employs dynamic capabilities theory to suggest that strategic routines and competencies, integrated value chains, sustainability-oriented transformations, and strategic organizational developments are the drivers to effectively develop dynamic capabilities. Similarly, environmental-oriented sustainability, sustainable strategic management, sustainable dynamic capabilities, stakeholder-centric approach, sustainable supply chain management, operational excellence, sustainable research and development (R\&D), and sustainability-oriented global business strategy are found to be the drivers to achieve overall corporate sustainability. Based on the findings, a conceptual model is proposed to obtain sustained competitive advantage by developing sustainable dynamic capabilities and achieving corporate sustainability.
\end{abstract}

Keywords: sustainability; dynamic capabilities; corporate; drivers

\section{Introduction}

Sustainable corporate development can only be achieved through a pragmatic strategy incorporating sustainability at its core along with sustainable business models $[1,2]$ (pp. 1-160), and to stay competitive, dynamic capabilities are key contributing factors to sustain competitive advantage in the ever-changing business landscape [3] (p. 393), [4,5]. Despite the importance and implications of dynamic capabilities and corporate sustainability for contemporary businesses, to date, only 15 studies have focused on dynamic capabilities and sustainability in an integrated manner $[1,4,6]$.

Organizations must take sustainability as a dynamic capability to sense new opportunities and threats, seize relevant opportunities, and reconfigure and transform according to the market dynamics $[2,7,8]$. Traditionally, sustainability practices have been driven by regulatory compliance requirements, but more recently businesses have started to focus on corporate sustainability through benchmarking against three key metrics: environmental, social, and governance (ESG), but this is only a static view. By focusing just on the ESG ratings, current sustainability practices will gradually become a market norm with no competitive advantage if sustainability is not considered to be a dynamic capability.

The dynamic capabilities theory put forward by Teece (2018) [9] is instrumental, but it does not extend the interrelationships of dynamic capabilities with corporate sustainability [2]. A recent systematic review of 33 articles emphasized the need for further research on the integrated themes of sustainability and dynamic capabilities to understand how sustainability could be converted into a dynamic capability [4]. The current industrial mindset does not encapsulate the full set of challenges and opportunities associated with sustainability. Although a reasonable amount of research work has been carried out on the 
theoretical development of sustainable business models, there is still a gap in understanding how sustainability can be integrated with the strategy of competitive advantage $[2,4,10,11]$.

The need for a better understanding of corporate sustainability and dynamic capabilities is evident from the fact that up to $90 \%$ of business model innovations fail, due to lack of understanding of the implementation of sustainability practices [2,11,12]. Overall, sustainability is still a part of corporate social responsibility (CSR) and is not a part of corporate strategy. Sustainability practices are adopted to match the market and industryspecific trends to keep up with competitors. Top management is primarily concerned with achieving better ESG ratings to demonstrate social responsibility to investors, limiting sustainability to a compliance requirement rather than being a capability to become a part of competitive advantage strategy $[2,7,8]$. The previous research studies focused either solely on dynamic capabilities or sustainability but did not take an integrative approach. This research attempts to understand how these two phenomena, when integrated, can lead to sustained competitive advantage $[4,11]$. Using dynamic capabilities theory, a concept of sustainable dynamic capabilities is proposed by suggesting that sustainability can act as a dynamic capability as its micro-foundations, drivers, and routines possess sensing, seizing, and transformative capabilities.

Hence the main objectives of this research paper are to capture the main drivers and themes of dynamic capabilities for large corporations and SMEs for both developed and developing countries, to capture the main drivers and themes of corporate sustainability for large corporations and SMEs in the developed and developing countries, and to investigate how sustainability can be converted into a dynamic capability to achieve competitive advantage.

To meet the mentioned research objectives, the following research questions are developed:

(RQ-1) What are the main themes and drivers of dynamic capabilities for large corporations and SMEs in both developed and developing countries?

(RQ-2) What are the main themes and drivers of corporate sustainability for large corporations and SMEs in both developed and developing countries?

(RQ-3) How can sustainability be converted into a dynamic capability to achieve competitive advantage?

This study will contribute to the literature by extending the dynamic capabilities theory in conjunction with corporate sustainability. The findings of this paper will equip practitioners to select the right routines, micro-foundations, and practices that will not only help businesses to develop dynamic capabilities but also enable them to achieve corporate sustainability effectively and efficiently.

\section{Purpose and Conceptual Background}

The World Commission on Environment and Development (WCED) defines sustainability as "the economic development that meets the needs of the present generation without compromising the ability of future generations to meet their own needs" [13]. A review of 540 journal articles has confirmed that sustainability is a growing research area but there is a gap in research between conceptual approaches and empirical insights $[2,6,11]$. Currently, the sustainability agenda is restricted to environmental impacts and eco-efficiency, but given the new challenges faced by businesses, companies need to integrate sustainability into business processes and business models to achieve a competitive advantage [10]. To maintain sustainability, innovations can no longer operate in silos, and an integrated set of dynamic capabilities are needed which should ultimately lead to a competitive advantage. The relationship between sustainability and competitive advantage is a focus for businesses to stay relevant and innovative $[1,2,4,5,8,14,15]$. Different sectors are directly impacted by sustainability challenges, and to have sustainable models of consumption and production, a focused approach is needed to develop and implement "sustainable business models", which is not possible until sustainability practices become sufficiently dynamic [6]. A recent case study of Deloitte has confirmed that even static organizational capabilities influence 
sustainable competitive advantage, but the agility and robustness of dynamic capabilities enable businesses to reconfigure and transform according to the market challenges and opportunities [16].

Interviews of 50 executives and a survey of 1500 experts conducted by the Boston Consulting Group have validated that the businesses which need new capabilities are directly dependent on superior organizational structural capabilities, which are dynamic and transformational $[17,18]$. In a framework of 20 organizational capabilities proposed by Roghe et al. (2012) [18], only dynamic capabilities have the potential to reconfigure and transform businesses over time. Dynamic capabilities are the specific tasks that, over time, provide organizations with a platform to convert these specific tasks into capabilities to overcome sustainability challenges [19], [20] (p. 4) and [21]. They provide procedures for specific tasks to become capabilities in the long term, and in a dynamic way that helps organizations to resolve sustainability issues in an effective way [20] (p. 4).

Dynamic capabilities can overcome sustainability challenges by constantly integrating, renewing, recreating, and reconfiguring resources to achieve sustained competitive advantage. Dynamic capabilities are the blueprint of how businesses could strategically match their resources and needs by discovering, defining, creating, and exploiting the entrepreneurial opportunities presented in the external environments of dense complexity and volatility $[3,5,21]$. Dynamic capabilities are both micro-foundation capabilities and higher-order capabilities. Micro-foundation capabilities are second-order capabilities that focus on redesigning, adjusting, and recombining the existing ordinary capabilities while developing new ones. Higher-order capabilities are used by management to sense future opportunities and threats, devise business models to seize opportunities, and reconfigure resources for competitive advantage. Establishing interfirm alliances leads to dynamic capabilities to positively impact the long-term organizational performance as well [3,22-24]. It is important to note that performance and competitive advantages can be achieved through dynamic capacities, but capabilities can co-evolve in different business systems $[4,21,25,26]$.

\section{Methodology: Protocols, Search Criteria, and Coding Classifications}

Following PRISMA guidelines, a systematic literature review (SLR) was conducted. The detailed methodological approach for this paper is presented in Figure 1. To ensure the credibility and integrity of this review, the following steps were carefully taken as recommended in previous research:

1. Identification of articles using the relevant database or top journals [4];

2. Classification and codification of articles [27];

3. Summary of each article's main objectives and results $[4,28,29]$;

4. Provision of gaps in knowledge and research and development of the conceptual framework $[4,30]$.

Previous systematic reviews of the literature used Web of Sciences (WoS) and Scopus databases for selecting articles, largely because in the research community WoS and Scopus are simply the most known databanks [4,28-32]. To complement the generic literature review and broaden the search horizon, Scopus and EBSCOhost databases were selected for this research. The following criteria were used to include or exclude the papers:

- Publications including conference papers within a ten-year duration (2011-2020) were selected [4,28-32];

- $\quad$ Papers published only in the English language were selected;

- The papers which had addressed both dynamic capabilities and sustainability in conjunction were selected. Some papers had used the word sustainable as a word and not as a phenomenon; those papers were rejected. 


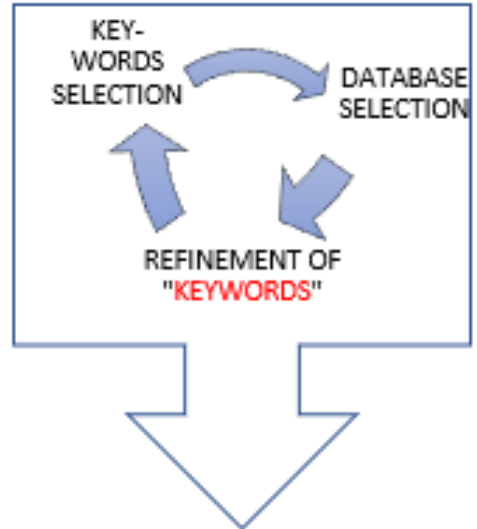

\section{STEP 2}
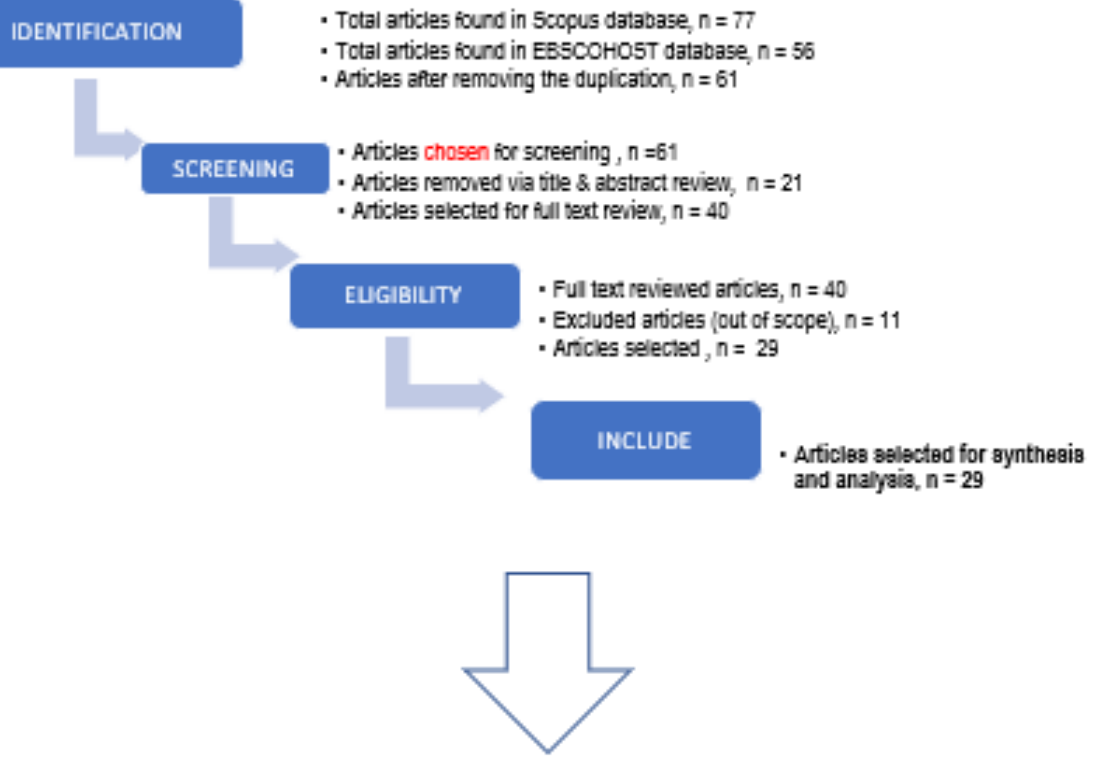

\section{PROPOSED CONCEPTUAL MODEL}

Figure 1. Research methodology to develop a proposed conceptual model.

Multiple search runs were carried out between April-July 2021. The most suitable and useful strings or combinations of these keywords were found to be sustainability, and "dynamic capabilities", corporate or drivers. Using this string of keywords, a total of 133 papers were found as follows:

In Scopus, the following keywords were used: sustainability, and "dynamic capabilities", and corporate or drivers. As a 77 result papers were obtained. In EBSCOhost (Business Source Ultimate), the following keywords were used: sustainability, and "dynamic capabilities", and corporate or drivers. As a result, 56 papers met the initial criteria. 
We removed 72 papers out of 133 as they were found to be duplicated, while the remaining 61 papers were selected for further review. After reading through the abstract and general body of knowledge, a further 21 papers were removed, and finally, after a detailed study of the papers, 29 were selected as they had used both the dynamic capabilities and sustainability themes in the papers.

\section{Classification and Coding}

A structured classification coding system was developed using the approach recommended in the literature view shown in Table 1. [4,28-32]:

\section{- Geographical context}

A code scale of (1-2) was used for the geographical context of the research studies focusing on both developing countries and developed countries (A), based on the works of $[4,28,32]$. OECD member countries were considered as the developed countries and the remaining were considered as developing countries for this study. The geographical context was based on the country in which the research study is carried out.

- $\quad$ Research focus

A code scale of (1-2) has been used for the research studies either using dynamic capabilities as a theory or focusing on the integrated themes of dynamic capabilities and sustainability (B), based on the works of Amui et al. (2017) [4] and Costa and Filho (2016) [31]. The research studies use dynamic capabilities theory to investigate organizational capabilities as a standalone phenomenon, and their main objective is not focused on understanding the interrelationship between sustainability and dynamic capabilities. These were coded as B1. The research papers aiming to understand the interrelated and integrated themes of dynamic capabilities and sustainability were coded as B2.

- Dimensions of dynamic capabilities

A code scale of (1-2) has been used for research studies discussing the dimensions of dynamic capabilities, either technical or commercial (human aspects) (C), based on the works of Govindan et al. (2015) [29] and Amui et al. (2017) [4].

\section{- Sector}

The sector focused on the research studies, either SME or large organizations (D), was coded on a (1-2) scale, based on the works of Amui et al. (2017) [4] and Jabbour (2013) [28].

\section{- $\quad$ Strategic focus}

With strategic focus, either sustainability was focused on as a dynamic capability to achieve the competitive advantage or discussed as an operational practice (E), coded on a (1-2) scale, based on the works of Amui et al. (2017) [4] and Papadopoulos et al. (2017) [30]. Sustainability as an operational practice is where it is used as a tool to achieve continuous improvement in operational aspects such as reducing carbon footprints and using green raw materials. Sustainability to achieve competitive advantage is where businesses strategically see sustainability as a differentiator to outperform their competitors; examples of such practices could be technological innovation and the development of innovative products.

- $\quad$ Research method

A code scale of (1-4) was used as per the research methods used in the research paper, e.g., case study, interviews, surveys, theoretical (F), based on the works of Amui et al. (2017) [4], Papadopoulos et al. (2017) [30] and Fahimnia et al. (2015) [32]. 
Table 1. Classification and coding framework.

\begin{tabular}{ccc}
\hline Classification & Codes \\
\hline Geographical context & Developed country & A1 \\
Research focus & Developing country & A2 \\
& Dynamic capability theory as the lens & B1 \\
Dynamic capabilities and sustainability & B2 \\
as the main theme & C1 \\
capabilities & Technical & C2 \\
Sector & Commercial (human aspects) & D1 \\
& SMEs & D2 \\
Strategic focus & Large companies & E1 \\
& Sustainability as the operational practice & E2 \\
Research method & Sustainability to achieve competitive & F1 \\
& advantage & F2 \\
& Case study & F3
\end{tabular}

All the routines, drivers, and micro-foundations for both dynamic capabilities and corporate sustainability were captured, then the similar concepts of these micro-foundations and routines were merged and finally, these common concepts were further integrated to obtain the final main themes of the drivers of dynamic capabilities and corporate sustainability as shown in Figure 2.

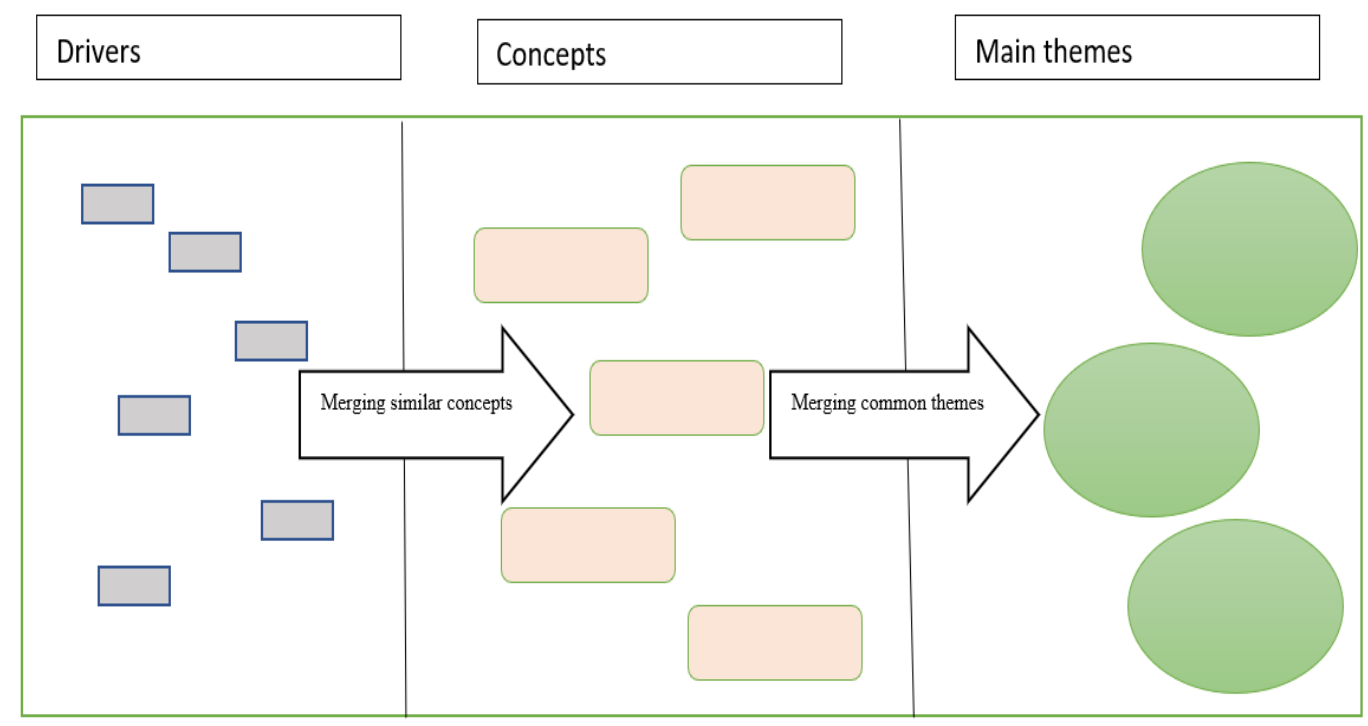

Figure 2. Coding process to obtain the main themes of drivers of dynamic capabilities and corporate sustainability.

Following the classification and coding system devised, a detailed study together with extensive note-keeping of all 29 papers was carried out. The drivers of dynamic capabilities and sustainability were captured and critically analyzed.

\section{Findings of Systematic Analysis}

The current status of research on the topics of dynamic capabilities and sustainability was determined by analyzing research papers through focusing on the key determinants such as the geographical context of the research, the research focus, the dimensions and types of dynamic capabilities discussed in the papers, the business sector, the strategic focus of the research, and the research methods used in the papers. 


\subsection{Geographical Context}

Most of the research papers (almost 62\%) focused on developed countries. Only 24\% of the research papers focused on the developing countries, creating a huge gap, and the remaining $14 \%$ of papers did not specify any geographical context, as shown in Figure 3.

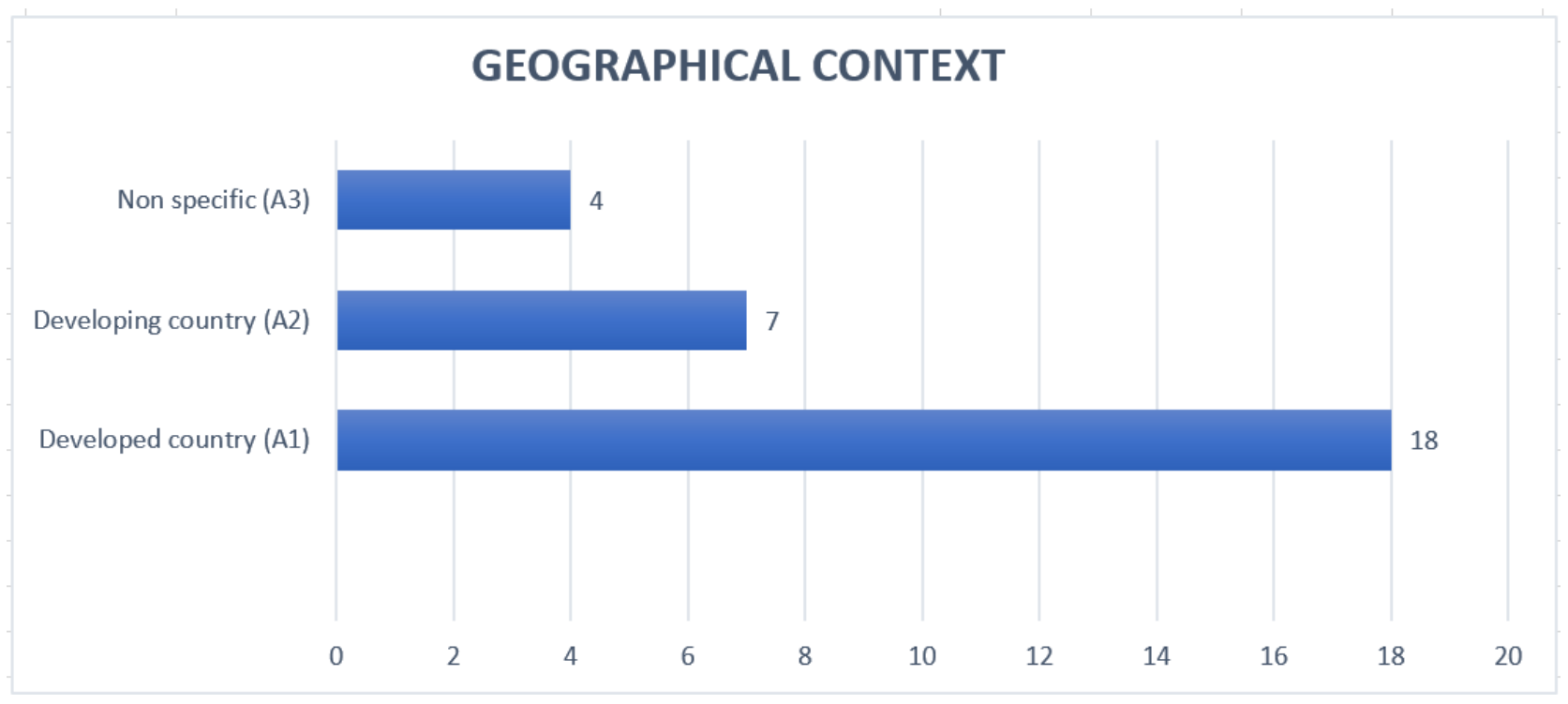

Figure 3. The geographical context of the research.

This bias, whether intentional or unintended, toward developed countries to understand the progression of dynamic capabilities and sustainability is omitting the business practices and challenges of the developing countries. One of the reasons for this exclusive focus on dynamic capabilities and sustainability in developed countries could be the stringent environmental regulations and compliance requirements in developed countries. Since developing countries are drawing level with developed countries in terms of having more awareness of sustainability issues and developing dynamic capabilities to achieve a competitive advantage, future research should be aimed at the developing countries as well. There is a dire need for a comparative study between the developed and developing countries to discuss the challenges and opportunities for developing dynamic capabilities and successfully implementing sustainability practices [33-43].

\subsection{Research Focus}

The research focus on the integration of dynamic capabilities and sustainability was overwhelmingly visible: $72 \%$ of the papers aimed at the combined themes of dynamic capabilities and sustainability; only $28 \%$ of the papers used dynamic capabilities as a theoretical lens just to understand the dynamics of the changing business landscape, without using it as a way forward to achieve sustainability, as shown in Figure 4.

Any transition toward corporate sustainability or functional sustainability could become challenging if organizations are not equipped to develop a set of dynamic capabilities. Dynamic capabilities are the established source to achieve competitive advantage [44-46] and are used as a strategy to redesign and adjust in the given changing business environment to sense threats, seize opportunities, and reconfigure according to the strategic requirements. There is a clear need for further research on the integrated themes of dynamic capabilities and sustainability as a vehicle to achieve sustained competitive advantage $[4,33,34,42,46-50]$. 


\section{RESEARCH FOCUS}

Dynamic capability theory as a lens (B1) a Dynamic capabilities and sustainability as the main theme (B2)

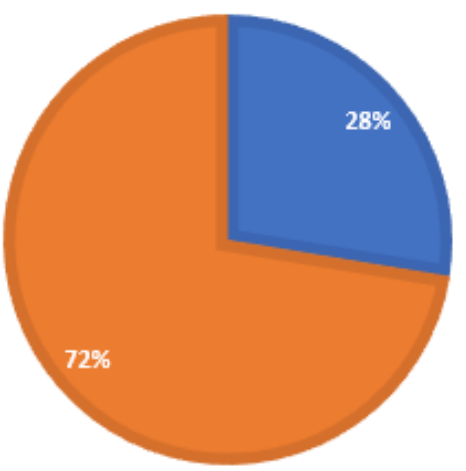

Figure 4. The research focus of the studies.

\subsection{Dimensions of Dynamic Capabilities}

Achieving operational efficiency through technological advancement and innovations was found to be the main area of research focus during the past 10 years. Fifty-two percent of the papers studied dynamic capabilities focusing on the technical aspects of the operation, while $48 \%$ of the papers discussed the commercial aspects of business-related development of the dynamic capabilities, as shown in Figure 5.

\section{DIMENSIONS OF DYNAMIC CAPABILITIES}

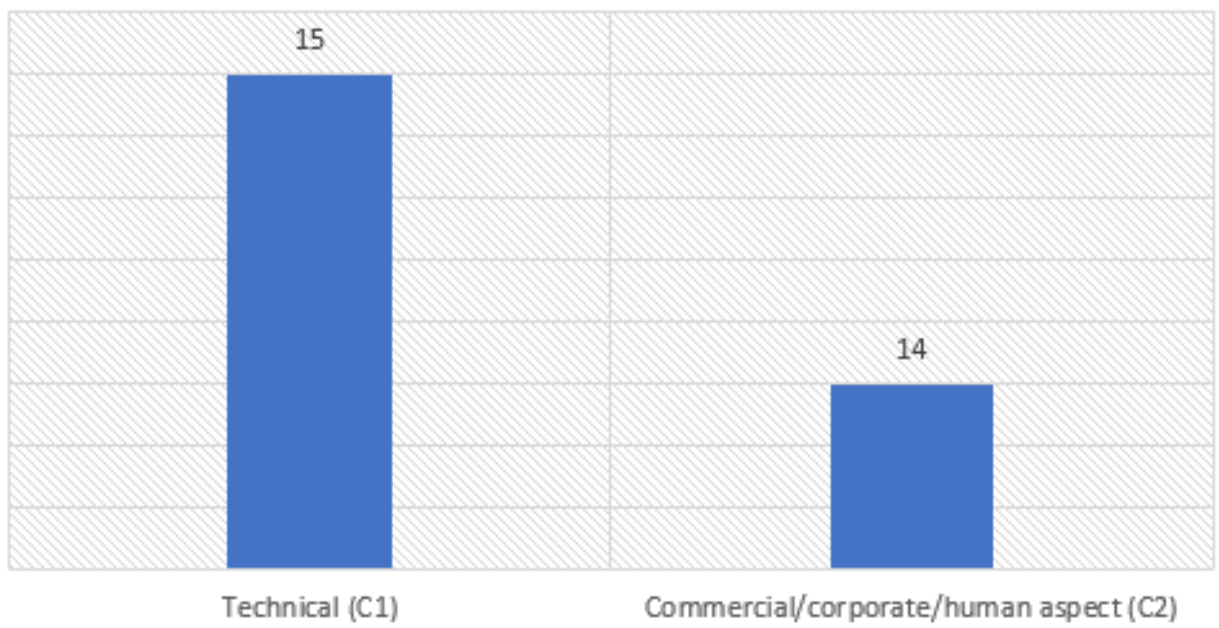

Figure 5. Dimensions of dynamic capabilities.

There is almost a uniform balance in research focusing on understanding dynamic capabilities to achieve technical innovation for operational efficiency and to address commercial and corporate challenges for businesses. It, therefore, highlights the actual implications and the importance of dynamic capabilities in the overall business. The development of dynamic capabilities through innovations in business models can lead to corporate sustainability and competitive advantage [35,46,51,52].

\subsection{Sector Focus in the Research Studies}

Large companies were the focus in $44.8 \%$ of the research studies, with only $17.2 \%$ of studies concentrating on SMEs, while $37.93 \%$ of the research papers had no specific focus, as shown in Figure 6. 


\section{SECTOR}

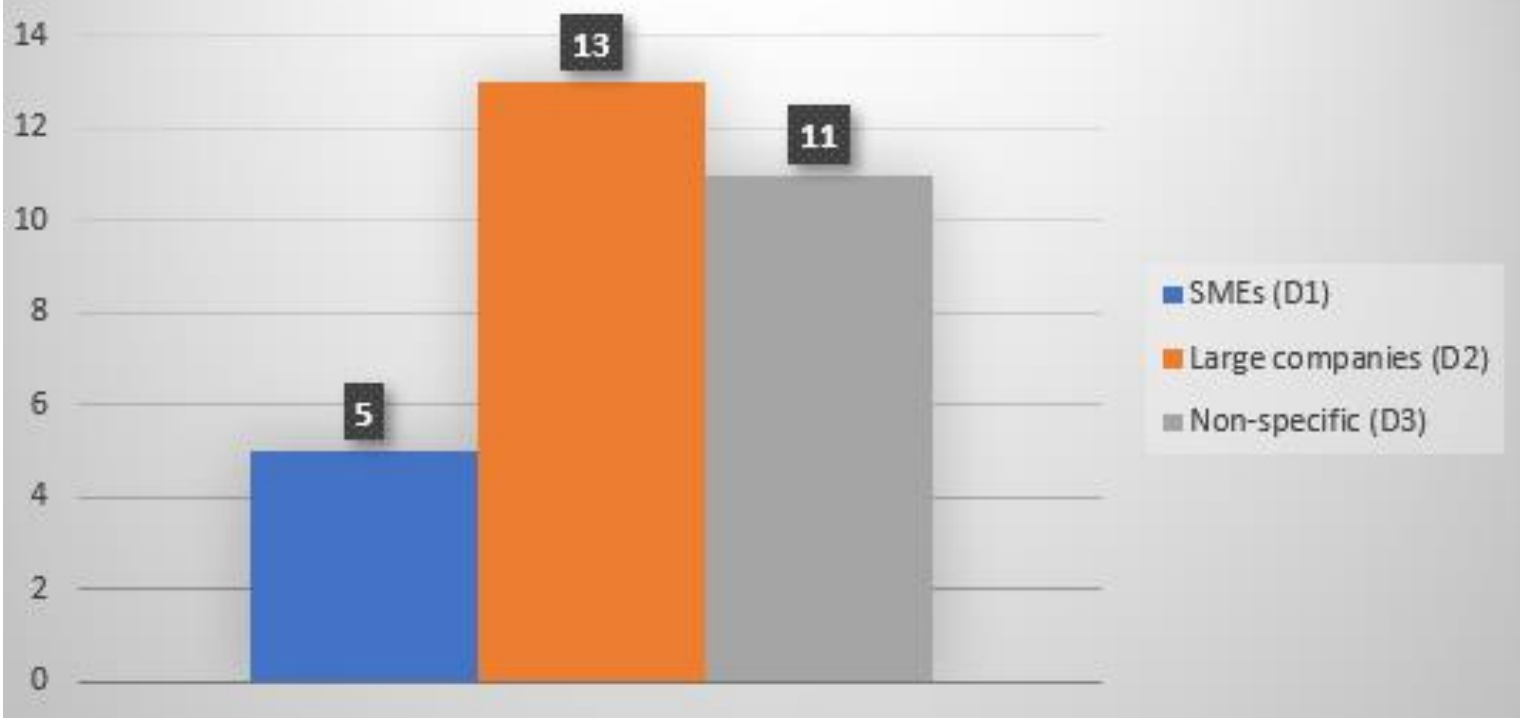

Figure 6. Sectors focused on the research studies.

The results demonstrate a clear inclination toward the large manufacturing-oriented companies as an area of interest for the past studies. This is perhaps due to the global focus on environmental regulations and emission reduction requirements, as large manufacturing companies are the main contributors of GHG emissions [37]. Another reason for this bias could be the availability of data and openness in large companies. Large organizations are publicly listed companies issuing corporate reports every year. SMEs, on the other hand, are mostly privately owned organizations with limited information made available to the public and restricted communication channels with the wider business community $[26,40,52]$.

\subsection{Strategic Focus}

Sixty-two percent of the research papers attempted to understand how sustainability can lead to competitive advantage, while $38 \%$ of the studies considered sustainability to achieve operational efficiency, as shown in Figure 7.

\section{STRATEGIC FOCUS}

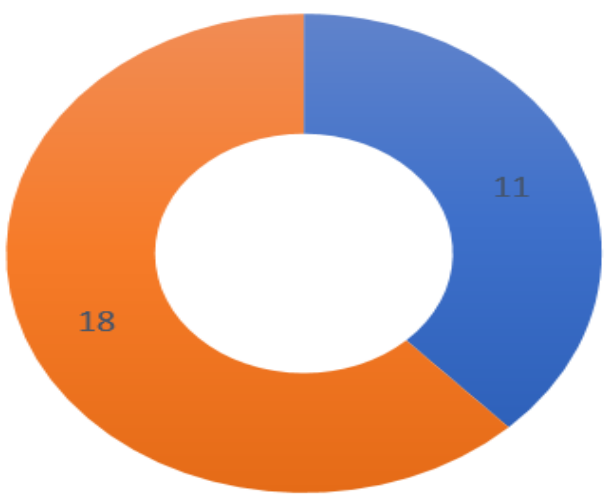

Sustainability as the operational practice (E1)

- Sustainability to achieve competitive advantage (E2)

Figure 7. The strategic focus of the research studies.

After extensive note-taking and strategically evaluating these 18 research papers focusing on competitive advantage, it can be anticipated that by developing sustainability- 
oriented dynamic capabilities, businesses can achieve corporate sustainability and competitive advantage $[4,33,34,42,44-50,53]$.

\subsection{Research Methods}

Twenty-seven-point-five percent of studies used the case study method, hence making it the most widely used methodology in past research. Almost $20.6 \%$ of papers conducted surveys to collect and analyze data, $17.2 \%$ of studies used quantitative methods to collect data, $13.7 \%$ of papers used expert interviews, and a further $13.7 \%$ and $6.89 \%$ of research papers were found to be systematic literature reviews and theoretical/conceptual studies, respectively, as shown in Figure 8.

RESEARCH METHOD

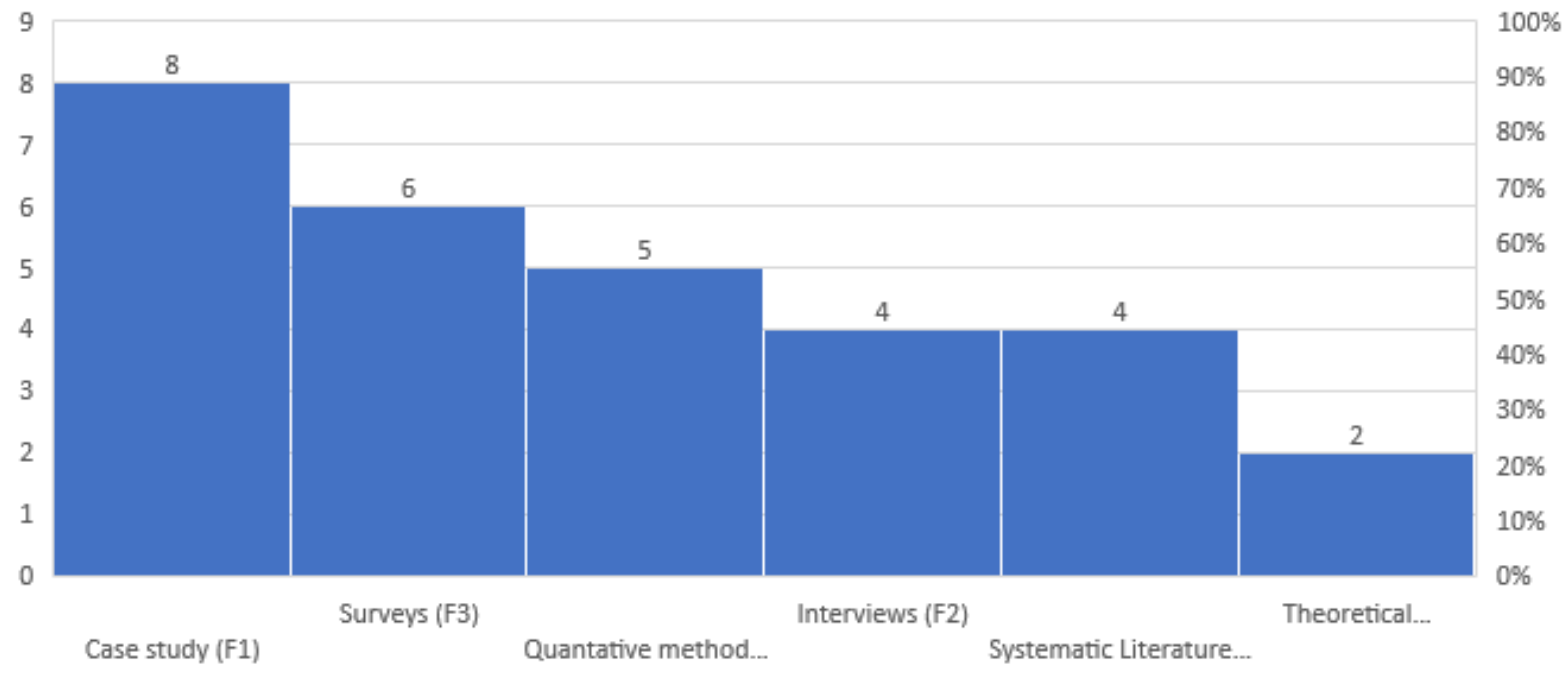

Figure 8. The research method employed by research studies.

Case studies were extensively conducted in past research because of the greater focus on large organizations. Given the amount of data, sample size, and ease of accessing the information in large organizations, case studies and surveys were chosen as the most popular research methodologies by the researchers in the past $[33,36-38,41,45,47,50,51,53-56]$, aiding them to collect and analyze data in a relatively short period. Quantitative methods were employed due to the orientation and focus of the past research, as most studies were designed to validate and verify the findings rather than frequently proposing, exploring, and exploiting new concepts. Expert interviews, systematic reviews, and conceptual studies were used in a limited way, and clearly demands better utilization and a more proactive approach toward using these methodologies allowed for a more comprehensive research approach $[34,35,39,40,42,44,46,52,57]$.

\subsection{Drivers of Organizational Dynamic Capabilities (RQ-1)}

This section unpacks the findings to address research question 1 (RQ-1) of this paper. As a result of an SLR of 29 papers, 82 drivers of dynamic capabilities were found, as shown in Table 2.

These abovementioned drivers comprised different routines, practices, and microfoundations about operational, organizational, and human aspects of the businesses. The following four main themes of these drivers were further extracted by merging the concepts. 
Table 2. The main drivers and themes of organizational dynamic capabilities.

\begin{tabular}{|c|c|c|c|}
\hline & Main Themes & Merging Concepts & Drivers \\
\hline \multirow{20}{*}{1.} & \multirow{20}{*}{$\begin{array}{l}\text { Strategic routines and compe- } \\
\text { tencies (SR) }\end{array}$} & \multirow{11}{*}{$\begin{array}{l}\text { Continuous proactivity as per changing } \\
\text { business landscape }\end{array}$} & $\begin{array}{l}\text { Increased monitoring, sensing, and seizing routines } \\
\qquad[39,42,49,51,54]\end{array}$ \\
\hline & & & Reconfiguring functional capabilities $[35,39]$ \\
\hline & & & Reconfiguring resources $[26,39,49]$ \\
\hline & & & Monitoring emerging sustainability needs [35] \\
\hline & & & Seizing and capturing sustainable opportunities $[35,57]$ \\
\hline & & & Organizational structure reconfiguration [56] \\
\hline & & & Implementing creative integration [26] \\
\hline & & & Build incremental capabilities [49] \\
\hline & & & $\begin{array}{l}\text { Enhanced renewing, regenerative, and absorptive } \\
\text { capabilities }[39,49]\end{array}$ \\
\hline & & & Acquiring new knowledge $[40,53,57]$ \\
\hline & & & Assimilate and exploit new insights $[40,55]$ \\
\hline & & \multirow{3}{*}{ Enhanced innovation activities and routines } & Collaborative innovation $[41,46,53]$ \\
\hline & & & $\begin{array}{l}\text { Enabling innovation structure and organizational } \\
\text { routines }[46,54]\end{array}$ \\
\hline & & & Production innovation $[34,49]$ \\
\hline & & \multirow{6}{*}{ Developing eco-capability } & Green initiatives and practices [57] \\
\hline & & & Green innovation and management $[12,45,53]$ \\
\hline & & & Green marketing [55] \\
\hline & & & Ecologically-oriented products and processes $[36,53]$ \\
\hline & & & $\begin{array}{l}\text { Eco-effectiveness, remapping, and reaping capabilities } \\
{[36]}\end{array}$ \\
\hline & & & Focusing on eco-centric competitive advantage $[4,36,53]$ \\
\hline & \multirow{13}{*}{ Integrated value chains (SC) } & \multirow{9}{*}{ Increased stakeholder engagement } & Balancing stakeholder value $[46,48]$ \\
\hline & & & $\begin{array}{l}\text { Alliance and partnership with stakeholders } \\
\qquad[34,41,42,48,49,53,54]\end{array}$ \\
\hline & & & $\begin{array}{l}\text { Addressing internal and external stakeholder challenges } \\
\qquad[35,56]\end{array}$ \\
\hline & & & $\begin{array}{l}\text { Capitalizing on stakeholder knowledge and engagement } \\
\qquad[41,49,53,57]\end{array}$ \\
\hline & & & Co-evolving and partnership development $[48,49,53]$ \\
\hline & & & Trustworthy relationships $[41,53]$ \\
\hline & & & $\begin{array}{l}\text { Multi-stakeholder enterprise model [58] } \\
\text { Exchange of information with internal and external } \\
\text { stakeholders }[41,47,53,58]\end{array}$ \\
\hline & & & Integrating and leveraging resources [26] \\
\hline & & & Qualitative partner control and auditing [48] \\
\hline & & \multirow{4}{*}{ Optimized supply chain } & Supply chain visibility [52] \\
\hline & & & Increased supplier modular design [52] \\
\hline & & & Supply chain flexibility and agility [52] \\
\hline & & & Supply chain integration and reconfiguration $[48,52]$ \\
\hline
\end{tabular}


Table 2. Cont.

\begin{tabular}{|c|c|c|c|}
\hline & Main Themes & Merging Concepts & Drivers \\
\hline \multirow{26}{*}{3.} & \multirow{26}{*}{$\begin{array}{l}\text { Sustainability-oriented trans- } \\
\text { formations (ST) }\end{array}$} & \multirow{7}{*}{ Sustainability focused initiatives } & Valuing business sustainability [46] \\
\hline & & & Sustainable development [54] \\
\hline & & & Push for corporate sustainability $[54,57]$ \\
\hline & & & Sustainability oriented innovations [41] \\
\hline & & & Sustainable processes and products [40] \\
\hline & & & Ecological sustainability [36] \\
\hline & & & Corporate social responsibility (CSR) [42] \\
\hline & & \multirow{8}{*}{$\begin{array}{l}\text { Environmental systems management and } \\
\text { routines }\end{array}$} & Circular economy [57] \\
\hline & & & Environmental proactivity [45] \\
\hline & & & $\begin{array}{l}\text { Implementing environment management systems (ISO, } \\
\text { etc.) [57] }\end{array}$ \\
\hline & & & Compliance with environmental regulations [41] \\
\hline & & & Pollution prevention $[43,53]$ \\
\hline & & & Clean technologies [43] \\
\hline & & & Environmentally oriented innovation [43] \\
\hline & & & Recycling technologies [53] \\
\hline & & \multirow{7}{*}{ Sustainable operational excellence } & Product stewardship [56] \\
\hline & & & Continuous process improvement [43] \\
\hline & & & Better service innovation [42] \\
\hline & & & Enhanced service delivery [42] \\
\hline & & & Product traceability $[48,56]$ \\
\hline & & & New resource development [53] \\
\hline & & & Better resource allocation [12] \\
\hline & & \multirow{4}{*}{ Innovative research and development $(\mathrm{R} \& \mathrm{D})$} & Technological developments $[41,56,57]$ \\
\hline & & & Adoption of advanced technology [34] \\
\hline & & & R\&D intensity [44] \\
\hline & & & Technological integration $[41,48]$ \\
\hline \multirow{14}{*}{4.} & \multirow{14}{*}{$\begin{array}{l}\text { Strategic organizational devel- } \\
\text { opment (OD) }\end{array}$} & \multirow{5}{*}{ Organizational learning } & People capability development $[45,46,53]$ \\
\hline & & & Human resources learning and development $[42,57]$ \\
\hline & & & Higher-order corporate learning $[45,53,57]$ \\
\hline & & & Knowledge assessment $[48,57]$ \\
\hline & & & Cognitive and learning of top management [42] \\
\hline & & \multirow{9}{*}{ Business model innovations } & Embracing ambiguity [46] \\
\hline & & & $\begin{array}{l}\text { Global connectedness and internationalization } \\
\qquad[41,44,53,57]\end{array}$ \\
\hline & & & Ambidexterity [50] \\
\hline & & & Leveraging on uncertainties and complexities [41,42] \\
\hline & & & Evolutionary changes [41] \\
\hline & & & Uncertainty mitigation and risk management $[41,42]$ \\
\hline & & & Reduce organizational slack [41] \\
\hline & & & Develop marketing capabilities [42] \\
\hline & & & Better brand management [41] \\
\hline
\end{tabular}


Table 2. Cont.

\begin{tabular}{|c|c|c|}
\hline Main Themes & Merging Concepts & Drivers \\
\hline & \multirow{9}{*}{ Strategic planning and corporate governance } & Strategic top management commitment $[42,57]$ \\
\hline & & Capital management [41] \\
\hline & & Alternation in firm's leadership [49] \\
\hline & & Company's rate of adoption $[49,57]$ \\
\hline & & Strategic organizational dynamics $[39,41,47,49,53,54]$ \\
\hline & & Aligning firm's strategic orientation [47] \\
\hline & & Cross-functional coordination [33] \\
\hline & & Change management [53] \\
\hline & & Collaborative organizational culture [53] \\
\hline
\end{tabular}

\subsubsection{Strategic Routines and Competencies}

To cope with the continuous changes in the business landscapes, organizations need to develop and enhance certain strategic competencies, routines, and micro-foundations which will ultimately be transformed into dynamic capabilities. These competencies enable businesses to sense opportunities and threats, seize and capitalize on the right opportunities, and finally reconfigure resources to mitigate the potential threats and pitfalls $[26,35,39,42,49,51,54]$.

Businesses can achieve sustained competitive advantage by developing a set of sustainable dynamic capabilities, by acquiring new knowledge and exploiting customer insights to develop, revise, and enhance sustainability-oriented competencies, routines, and microfoundations $[35,40,53,56,57]$. Through collaborating with internal and external stakeholders, including customers, businesses can drive innovations in production systems, operations, processes, and organizational structures which will ultimately lead to the development of sustainable dynamic capabilities $[34,46,49,53,54]$. Eco-capabilities are essentially sustainable dynamic capabilities that are developed through driving green initiatives and innovations, ensuring businesses achieve eco-centric competitive advantage to outperform their competitors $[12,36,45,53]$.

\subsubsection{Integrated Value Chains}

Through developing alliances and trustworthy relationships with stakeholders, businesses can capture customer values, enhance knowledge, and implement an integrated approach to reconfigure resources and business models. This adaptation and reconfiguration of business models and resources will lead to the development of sustainable dynamic capabilities, which will equip organizations to cope with market challenges and operate successfully in dynamic business environments [35,41,48,49,53,57].

By integrating the full value chain, and having an inclusive and focused approach toward stakeholders, organizations can develop capabilities to achieve optimized, sustainable, and agile supply chain management operations. These value chain-focused capabilities will not only become a source of competitive advantage but will act as sustainable dynamic capabilities for the businesses [48,52].

\subsubsection{Sustainability-Oriented Transformations}

There has been an increased focus by businesses on achieving corporate sustainability in the past decade. This transformation by businesses toward the implementation of sustainability-oriented practices and optimized processes drives organizations to develop sustainable dynamic capabilities which will enable them to behave in a more socially responsible way and develop innovative products to achieve a competitive advantage $[36,42,54,57]$. The starting point of such transformations is usually through implementing environmental management systems. By having such systems in place, businesses not only reduce their carbon footprints, comply with the international environmental regulations, and develop green and eco-friendly products, but also act proactively to reconfigure, revise, and readjust 
their existing competencies and capabilities. These practices become the drivers of sustainable dynamic capabilities through incorporating environmentally-conscious decision-making and developing sustainability-oriented products, which will ultimately lead to competitive advantage $[41,43,53]$.

As natural resources are becoming more and more scarce, firms are keen to obtain the maximum output from their resource base, hence continuously improving processes, systems, and products to make them more sustainable. In doing so, organizational routines and competencies are renewed, readjusted, and reconfigured, leading to the development of sustainable dynamic capabilities [12,42,43,48,56]. The need for the development of technologically advanced products, and the implementation of innovative solutions through intensive research and development, drive a shift toward developing sustainable dynamic capabilities [41,42,44,48,56,57].

\subsubsection{Strategic Organizational Development}

By developing human resources, acquiring a new knowledge base, and developing top management personnel by enhancing their cognitive abilities and learning capabilities, organizations can evolve and develop a set of sustainable dynamic capabilities [42,45,48,53,57]. Given the changing dynamics of international businesses, and the way corporate organizations work in this age and time, more and more companies are going global by setting up operations and contracts in different parts of the world. This new paradigm of international business and globalization helps businesses to develop a unique and sustainable set of dynamic capabilities to achieve a competitive advantage based on innovation, improved brand image, reduced organizational slack, innovating existing business models, international experiences, knowledge assessments, and expertise in different geographical locations [41,42,44,49,50,53].

The strategic developments and shifts in organizations are driven by top management personnel. Their commitment to driving such changes induces a new organizational culture for better capital management and organizational dynamics. This strategic commitment brings about interfirm coordination, corporate development, and effective change management, which will lead to the development of sustainable dynamic capabilities for companies to achieve competitive advantage $[39,41,42,47,49,53,54,57]$.

\subsection{Drivers of Corporate Sustainability (RQ-2)}

This section discusses the findings that address research question 2 (RQ-2) of this paper. The SLR of 29 papers revealed 57 drivers of corporate sustainability, as shown in Table 3.

Table 3. Drivers of corporate sustainability.

\begin{tabular}{|c|c|c|c|}
\hline & Main Themes & Merging Concepts & Drivers \\
\hline \multirow{9}{*}{1.} & \multirow{9}{*}{$\begin{array}{l}\text { Environmental- } \\
\text { oriented sustainabil- } \\
\text { ity (ENS) }\end{array}$} & $\begin{array}{l}\text { Environmentally-driven } \\
\text { innovations }\end{array}$ & $\begin{array}{l}\text { Environmental sustainability innovation } \\
\qquad[4,33,37,39-41,53]\end{array}$ \\
\hline & & \multirow[t]{6}{*}{ Green innovation strategy } & Green innovation $[4,12,33,37,40,41,45]$ \\
\hline & & & Green supply chain $[33,38]$ \\
\hline & & & Green human resources $[26,42,55]$ \\
\hline & & & Green environmental management [34] \\
\hline & & & Green marketing [55] \\
\hline & & & Green corporate strategy $[33,40]$ \\
\hline & & \multirow[t]{2}{*}{$\begin{array}{l}\text { Environmental compliance } \\
\text { requirements }\end{array}$} & $\begin{array}{l}\text { Environmental regulations } \\
\qquad[26,33,34,40,43,47]\end{array}$ \\
\hline & & & Pollution prevention $[33,43,53]$ \\
\hline
\end{tabular}


Table 3. Cont.

\begin{tabular}{|c|c|c|c|}
\hline & Main Themes & Merging Concepts & Drivers \\
\hline & & \multirow{4}{*}{$\begin{array}{l}\text { Ecological sustainable } \\
\text { development }\end{array}$} & Ecological sustainability [36] \\
\hline & & & Eco-efficiency $[36,43]$ \\
\hline & & & Eco-design capabilities $[4,12,37]$ \\
\hline & & & Eco-innovation $[12,26,36,38,40,41]$ \\
\hline & & \multirow{3}{*}{$\begin{array}{c}\text { Environmental management } \\
\text { strategy }\end{array}$} & $\begin{array}{l}\text { Environment management strategy } \\
\qquad[26,33,39]\end{array}$ \\
\hline & & & $\begin{array}{l}\text { Implementation of environmental } \\
\text { management systems }[26,38,39,49,57]\end{array}$ \\
\hline & & & Environmental regulations $[33,47]$ \\
\hline & & \multirow{3}{*}{$\begin{array}{l}\text { Waste management and } \\
\text { recycling }\end{array}$} & Water conservation [33] \\
\hline & & & Circular economy $[26,40,47,53,55]$ \\
\hline & & & Dematerialization $[40,43]$ \\
\hline \multirow{16}{*}{2.} & \multirow{16}{*}{$\begin{array}{l}\text { Sustainable strategic } \\
\text { management (SR) }\end{array}$} & $\begin{array}{l}\text { Business process } \\
\text { re-engineering }\end{array}$ & $\begin{array}{l}\text { Sustainable business model innovations } \\
\text { (SMBIs) }[39,46,49]\end{array}$ \\
\hline & & \multirow{10}{*}{$\begin{array}{l}\text { Corporate sustainability } \\
\text { strategy }\end{array}$} & $\begin{array}{l}\text { Corporate sustainable development } \\
{[12,33,36,43,47,53,54]}\end{array}$ \\
\hline & & & $\begin{array}{c}\text { Corporate sustainability performance } \\
{[12,33,34,43,47,50,51]}\end{array}$ \\
\hline & & & Change in the management practices $[36,39]$ \\
\hline & & & $\begin{array}{c}\text { Firm's DNA, ideology, and societal } \\
\text { engagement }[33,36,39]\end{array}$ \\
\hline & & & $\begin{array}{c}\text { Corporate synergies beyond regulatory } \\
\text { compliance, sustainability networking, and } \\
\text { leadership }[39,43,52,53]\end{array}$ \\
\hline & & & $\begin{array}{l}\text { Learning and cognitive competence of top } \\
\text { management }[42,49,55]\end{array}$ \\
\hline & & & Organizational restructuring $[42,55]$ \\
\hline & & & $\begin{array}{l}\text { Resource co-specialization strategy } \\
{[39,40,47]}\end{array}$ \\
\hline & & & Social entrepreneurship $[33,43]$ \\
\hline & & & A systematic approach toward society [49] \\
\hline & & \multirow{5}{*}{$\begin{array}{l}\text { Top management } \\
\text { commitment }\end{array}$} & Organizational agility [44] \\
\hline & & & Organizational learning $[38,39,45,53,55]$ \\
\hline & & & Corporate culture $[33,38,39,53]$ \\
\hline & & & Strategic commitment $[38,49,55]$ \\
\hline & & & Ambidexterity strategy $[50,55]$ \\
\hline \multirow{4}{*}{3.} & \multirow{4}{*}{$\begin{array}{l}\text { Sustainable } \\
\text { dynamic } \\
\text { capabilities (SDC) }\end{array}$} & \multirow{4}{*}{$\begin{array}{l}\text { Dynamic capabilities } \\
\text { development }\end{array}$} & $\begin{array}{c}\text { Capacity to sense, seize, reconfigure, and } \\
\text { collaborate } \\
{[12,33,39-43,45-47,49,51,52,56,57]}\end{array}$ \\
\hline & & & $\begin{array}{c}\text { Green dynamic capabilities } \\
{[12,36,39-41,49,55]}\end{array}$ \\
\hline & & & $\begin{array}{c}\text { Overcoming internal and external } \\
\text { stakeholder challenges } \\
{[4,12,33,35,39,40,43,46,47,49,56]}\end{array}$ \\
\hline & & & $\begin{array}{l}\text { Sustainability market orientation } \\
{[12,40,41,43,44,49,55,57]}\end{array}$ \\
\hline
\end{tabular}


Table 3. Cont.

\begin{tabular}{|c|c|c|c|}
\hline & Main Themes & Merging Concepts & Drivers \\
\hline \multirow{5}{*}{4.} & \multirow{5}{*}{$\begin{array}{l}\text { Stakeholder- centric } \\
\text { strategic approach } \\
\text { (SS) }\end{array}$} & \multirow{5}{*}{ Stakeholder management } & $\begin{array}{l}\text { Push sustainability agenda to internal and } \\
\text { external stakeholders }[33,40,43,47,56]\end{array}$ \\
\hline & & & $\begin{array}{l}\text { Multi-stakeholder enterprise model } \\
\qquad[34,36,39,40,42-44,49,58]\end{array}$ \\
\hline & & & $\begin{array}{c}\text { Exchange of communication between } \\
\text { internal and external resources } \\
{[33,34,36,43,56]}\end{array}$ \\
\hline & & & $\begin{array}{l}\text { Trustworthy relationship with stakeholders } \\
{[[33,39,40,44,47,49,53]}\end{array}$ \\
\hline & & & Partnership diversity [39] \\
\hline \multirow{4}{*}{5.} & \multirow{4}{*}{$\begin{array}{l}\text { Sustainable supply } \\
\text { chain management } \\
\text { (SC) }\end{array}$} & \multirow{4}{*}{$\begin{array}{l}\text { Supply chain management } \\
\text { and optimization }\end{array}$} & $\begin{array}{l}\text { Strategic supply chain collaborations } \\
{[33,52,53,56]}\end{array}$ \\
\hline & & & $\begin{array}{l}\text { Supply chain optimization and increased } \\
\text { supplier modular design }[52,56]\end{array}$ \\
\hline & & & $\begin{array}{l}\text { Sustainable supply chain management } \\
{[4,12,33]}\end{array}$ \\
\hline & & & $\begin{array}{l}\text { Improved supply chain management } \\
\text { decision-making (Medina-Serrano 2019) [56] }\end{array}$ \\
\hline \multirow{3}{*}{6.} & \multirow{3}{*}{$\begin{array}{l}\text { Operations } \\
\text { lence }(\mathrm{OE})\end{array}$} & \multirow{3}{*}{$\begin{array}{l}\text { Process and product } \\
\text { optimization }\end{array}$} & $\begin{array}{l}\text { Life cycle analysis (LCA) of products and } \\
\text { processes }[41,48,52,55]\end{array}$ \\
\hline & & & Product stewardship $[41,43,52]$ \\
\hline & & & Operational optimization $[33,40,52,53]$ \\
\hline \multirow{4}{*}{7.} & \multirow{4}{*}{$\begin{array}{l}\text { Sustainable research } \\
\text { and development } \\
(\text { R\&D) }\end{array}$} & \multirow{4}{*}{ Technological innovation } & Technological push $[26,38,40,42-44,55]$ \\
\hline & & & $\begin{array}{l}\text { Research and development (R\&D) intensity } \\
\qquad[4,38,40,43,44,53,55]\end{array}$ \\
\hline & & & Service innovation $[40,42,55]$ \\
\hline & & & $\begin{array}{l}\text { Collaboration among R\&D stakeholders } \\
\qquad[33,38,42]\end{array}$ \\
\hline \multirow[t]{2}{*}{8.} & \multirow{2}{*}{$\begin{array}{lr}\text { Sustainability- } \\
\text { oriented } & \text { global } \\
\text { business } & \text { strategy } \\
\text { (SGS) } & \end{array}$} & $\begin{array}{l}\text { Internationalization and } \\
\text { global business strategy }\end{array}$ & $\begin{array}{l}\text { Globalization and internal interconnectivity } \\
\qquad[43,44,47,50,53,57]\end{array}$ \\
\hline & & $\begin{array}{l}\text { Sustainability-oriented } \\
\text { marketing management }\end{array}$ & $\begin{array}{l}\text { Sustainability-oriented product branding } \\
\text { and market valuation }[33,44,49]\end{array}$ \\
\hline
\end{tabular}

The main concepts of these drivers were further merged to obtain eight main themes which would drive sustainability in organizational settings. The details of these main themes are as follows.

\subsubsection{Environmentally-Oriented Sustainability}

Activities and practices strategically focused on delivering environmental-oriented innovations in organizations drive a shift toward achieving corporate sustainability $[4,33,37,39-41,53]$. Businesses that prioritize the evaluation of the impact of their products and operations on the environment and ecosystems they function in act responsibly, recycle resources more effectively, and develop more innovative, green, and ecofriendly products $[26,33,34,40,43,47]$. These organizations tend to adopt green methodologies and principles in a wide range of business processes and operations; for example, supply chain management, human resource management, marketing management, and corporate strategy, hence achieving corporate sustainability as a result $[4,12,26,33,34,37,40-43,45,47,53,55]$.

Firms that are focused on implementing environmental management systems, initially to comply with the international environmental regulation requirements, also find that achieving sustainability could be the outcome in different business operations of the organization. Standalone quality assurance and environmental compliance systems and procedures become the drivers of overall corporate sustainability for these businesses [26,33,38,39,47,49,57]. 


\subsubsection{Sustainable Strategic Management}

Business model innovations are to be strategically aligned with the overall corporate sustainability strategy. Firms need to consider business model innovations as more than just a way to address compliance and regulatory concerns $[39,43,49,52,53]$. Top management plays the most critical role in driving corporate sustainability by clearly demonstrating their commitment to this shift by allocating the required resources, ensuring they revise, renew, and update management practices, and aligning the firm's ideology on broader societal engagements $[33,36,39,49]$. This successful transition would require organizational restructuring, continuous upgrading of organizational know-how, a change in the corporate culture, making the organization more agile, and adopting ambidextrous strategies [38,39,44,50,53].

Businesses that proactively aim to adopt sustainable development goals extract benefits of overall better corporate performance in all key indicators including the triple bottom line. This path toward achieving better performance through implementing sustainable goals and practices will display positive results in almost every aspect of the business while ultimately driving the businesses to achieve corporate sustainability and competitive advantage $[12,33,36,43,47,53,54]$.

\subsubsection{Sustainable Dynamic Capabilities}

The development of sustainable dynamic capabilities is found to be a major driver for businesses to achieve corporate sustainability. Through developing these sustainablyoriented dynamic capabilities, organizations can sense viable opportunities as well as relevant threats well in advance, seize the right opportunities, and ultimately reconfigure their resources to achieve strategic targets $[12,33,39,40,42,43,45-47,49,51,52,56,57]$. Organizations can develop sustainable dynamic capabilities by incorporating an ecological focus in their routines and micro-foundations while addressing internal and external stakeholder challenges $[4,12,33,35,39,40,43,46,47,49,56]$. All of these ecologically and sustainabilityoriented micro-foundations, routines, and competencies will fall under the umbrella of the dynamic capabilities of sensing, seizing, and reconfiguring [12,33,36,40,41,43,49,55,57].

\subsubsection{Stakeholder-Centric Strategic Approach}

Corporate sustainability is a real sense can only be achieved if all the internal and external stakeholders are brought on board not only to adopt the sustainability agenda but also to promote it. This requires the adaptation of the multi-stakeholder enterprise model, which is heavily dependent on the continuous exchange of communication between stakeholders $[33,34,36,39,40,43,44,47,49,56,58]$. Partnership diversity among the stakeholders acts as the catalyst to increase the overall trustworthiness to rejuvenate efforts toward promoting the sustainability agenda $[33,39,40,44,47,49,53]$.

\subsubsection{Sustainable Supply Chain Management}

Incorporating sustainability in different supply chain operations while collaborating with different supply chain partners will optimize the overall supply chain delivery, add value to the operation by providing a socially responsible, efficient, and agile perspective, and help businesses in reaching better decisions $[33,52,53,56]$. This integrative sustainable supply chain operation will essentially deploy the supplier modular design in practice, to effectively drive corporate sustainability for organizations [4,12,33].

\subsubsection{Operations Excellence}

Businesses can optimize their operations for excellence through championing product stewardship and by conducting regular product life cycle analysis for the full range of their products and processes $[41,43,48,52,53]$. By making operations more agile, reducing the carbon footprint from operations, products and processes, and by regularly evaluating and eliminating the products with higher environmental impact, organizations can lead a change to achieve operational as well as corporate sustainability $[33,40,52,53]$. 


\subsubsection{Sustainable Research and Development (R\&D)}

To stay competitive, businesses continuously thrive on developing innovative and technologically advanced products through their research and development initiatives. By having a sustainability perspective in research and development practices and projects, organizations can develop eco-friendly, environmentally efficient, socially responsible, technologically advanced, internationally compliant, resource and energy-efficient, and competitive products $[26,38,40,42-44,55]$. Collaborating with all stakeholders while undertaking research and development initiatives will not only help businesses understand the full range of stakeholder challenges and needs, but will also bring service innovation in operations and practices. This collaboration results in developing innovative products as well as offering innovative services, validated by the stakeholders, driving a shift toward corporate sustainability for organizations $[33,38,40,42,53]$.

\subsubsection{Sustainability-Oriented Global Business Strategy}

To enter international markets, businesses face a myriad of compliance, social, operational, and regulatory requirements specific to the market they wish to enter. Globalization has now exposed businesses to a new set of challenges and opportunities unique to both developing and developed countries. Given the societal differences, and growing compliance and regulatory requirements, firms need to adopt sustainability-focused business strategies to overcome these new sets of challenges and to successfully capitalize on opportunities in the maximum number of countries $[43,44,47,50,53,57]$. When sustainability becomes a part of marketing, branding, corporate communication, and product management, it increases product demand, corporate brand image, and valuation, which leads to the overall sustainability of the business globally $[33,44,49]$.

\subsection{Dynamic Capabilities and Corporate Sustainability for Competitive Advantage (RQ-3)}

In this section, based on the findings of systematic reviews, propositions have been put forward for a conceptual framework to achieve sustained competitive advantage through developing sustainable dynamic capabilities and achieving corporate sustainability, which will address research question 3 (RQ-3) of this paper.

There is a relationship between dynamic capabilities and sustained competitive advantage focusing on stakeholders' involvement. It has been found that the following dynamic capabilities-opportunity sensing capability, reconfiguration capability, organizational flexibility capability, and technological flexibility capability - have led to the development of a strategic alliance with the stakeholder, which further ensures the achievement of sustained competitive advantage, as shown in Figure 9 [3].

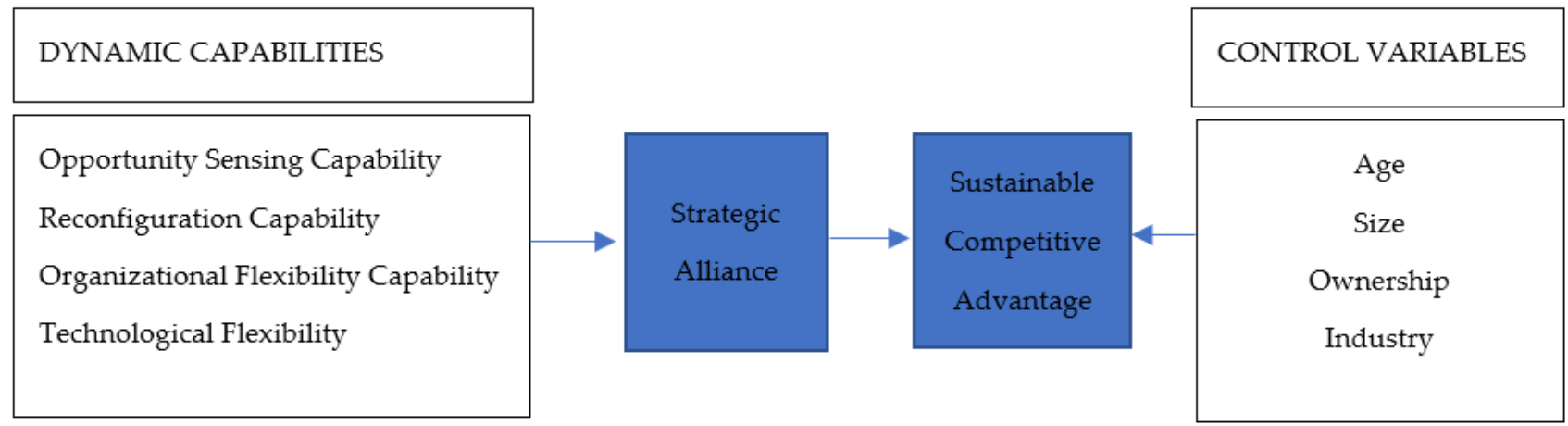

Figure 9. Dynamic capabilities and sustainable competitive advantage model [3].

Focusing on the supply chain sector, Beske (2012) [21] proposed a framework highlighting the current nature of dynamic capabilities, which was only contributing to a temporary competitive advantage, and suggested that to achieve a long-term competitive advantage, newly oriented dynamic capabilities were needed, as shown in Figure 10. 


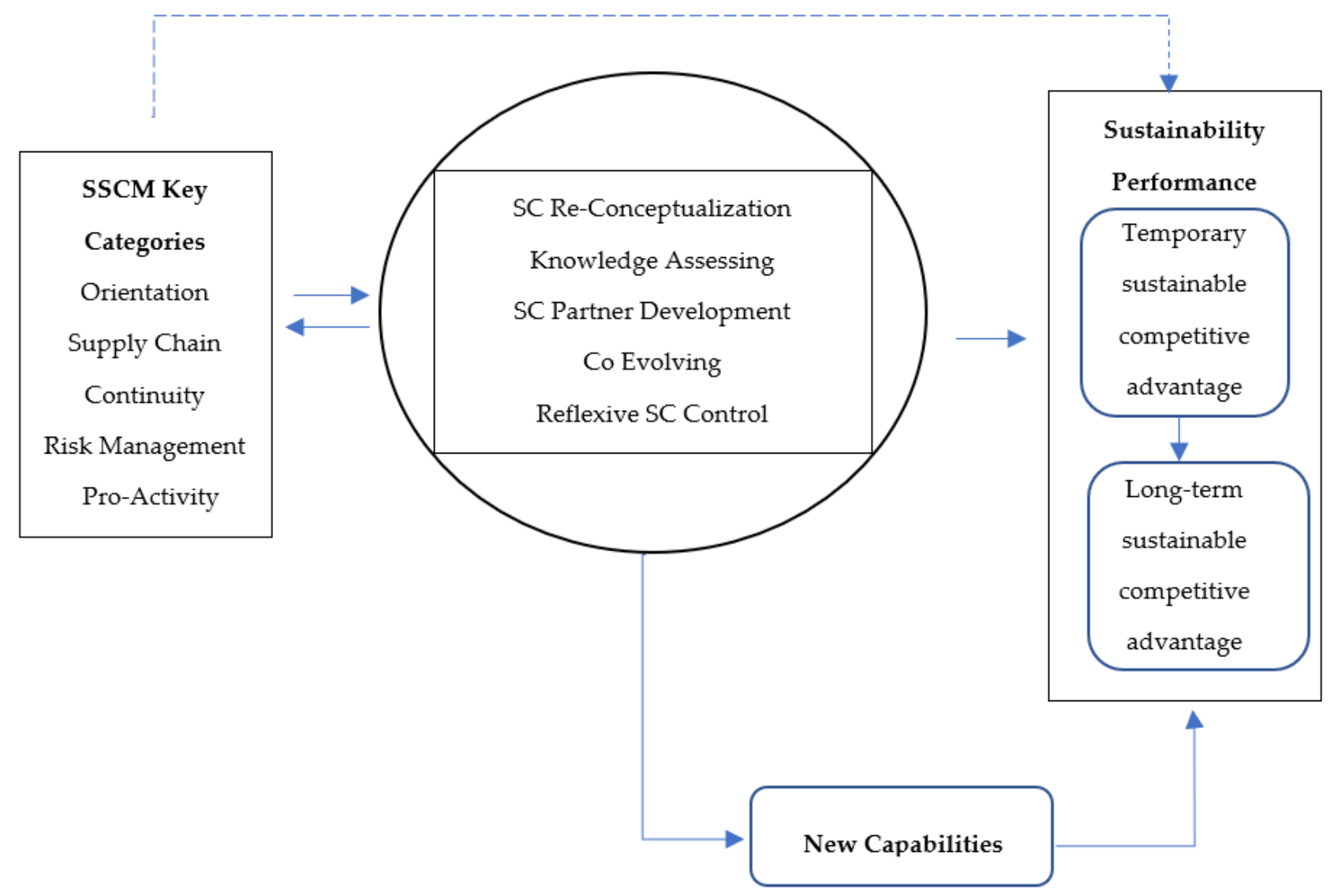

Figure 10. Framework for dynamic capabilities [21].

Hence, businesses should start incorporating the sustainability perspective into a dynamic capabilities viewpoint. In practice, organizations should focus on the routines, competencies, and practices which have a sustainable outlook and have a positive long-term impact on the environment, economy, and society. In this way, organizations can have a set of dynamic capabilities that will be more sustainable while also delivering sustained competitive advantage, rather than short-term competitiveness. Hence it is proposed that sustainable dynamic capabilities lead to sustained competitive advantage [12,36,40,41,43,44,49,55,57].

P1: Sustainable dynamic capabilities lead to sustained competitive advantage

Considering the drivers of dynamic capabilities and corporate sustainability in an integrated manner, these two phenomena have a direct relationship with each other in a way that they drive each other simultaneously. While critically analyzing the main themes of drivers of dynamic capabilities and sustainability, it was found that there were many common routines and micro-foundations between them. Furthermore, sustainable dynamic capabilities, where the competencies are developed into long-term capabilities having a sustainability focus at heart, were demonstrated as the major drivers to achieve corporate sustainability for the organization. Hence it is proposed that sustainable dynamic capabilities lead to corporate sustainability $[4,12,26,33,37,40-43,45,47,53]$.

P2: Sustainable dynamic capabilities lead to corporate sustainability

At the same time, the drivers of corporate sustainability entail practices that act as the drivers leading to sustainable dynamic capabilities, for example, sustainability-oriented transformations were found to be one of the key drivers to achieve sustainable dynamic capabilities. Hence it is proposed that corporate sustainability leads to sustainable dynamic capabilities [12,38,40-43,45,53,55].

P3: Corporate sustainability leads to sustainable dynamic capabilities 
Corporate sustainability needs to be considered an integral part of a business strategy to achieve sustained competitive advantage, as the sustainability of dynamic capability and competitive advantage should be dependent on the persistence of the overall corporate sustainability of the organization. Hence it is further proposed that corporate sustainability acts as a mediator between sustainable dynamic capabilities and sustained competitive advantage [41,42,44,48,56,57].

P4: Corporate sustainability acts as a mediator between sustainable dynamic capabilities and sustained competitive advantage

A conceptual model is based on the above propositions. This demonstrates the interrelationship between sustainable dynamic capabilities, corporate sustainability, and sustained competitive advantage. Developing sustainable dynamic capabilities is a path toward achieving corporate sustainability and sustained competitive advantage. Corporate sustainability is not a standalone concept; rather it is a function of mediation between the sustained dynamic capabilities and sustained competitive advantage, while acting as a path to develop sustainable dynamic capabilities for the organization, as shown in Figure 11.

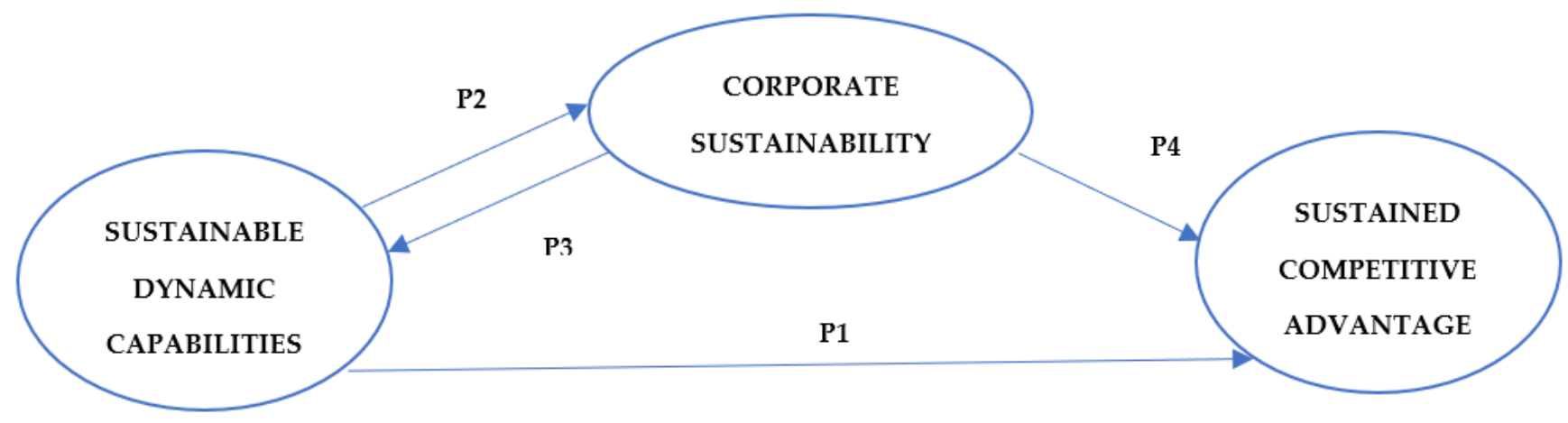

Figure 11. A conceptual model to achieve sustained competitive advantage by sustainable dynamic capabilities through corporate sustainability.

\section{Discussion}

This section will discuss the interrelationship between the drivers of dynamic capabilities and corporate sustainability as well as their impact on large corporations and SMEs.

\subsection{Dynamic Capabilities for Large Corporations and SMEs in Developed and Developing Countries (RQ-1)}

There is a contrast between the drivers of dynamic capabilities when it comes to the implementation of the routines and micro-foundations of drivers of SMEs and large corporations in developed and developing countries, as shown in Table 4. Implementing strategic routines and competencies is found to be a high-impact driver to develop dynamic capabilities for large corporations operating in developed countries, but maintains medium impact on developing the organizational dynamic capabilities given the size of the businesses and limited strategic approach toward developing dynamic capabilities [26,35,39,43,49,51,54].

Integrated value chains very strongly impact the business transformation to develop dynamic capabilities in large corporations such as multinational companies, which have high importance in both developed and developing countries. Since SMEs do not usually have full inhouse value chain operations and are mostly a part of the total value chain, these competencies have a medium impact on such businesses to acquire dynamic capabilities [48,52]. 
Table 4. Drivers of organizational dynamic capabilities with impact factor.

\begin{tabular}{cccccc}
\hline Drivers & Codes & $\begin{array}{c}\text { Large Corp } \\
\text { (D1) }\end{array}$ & $\begin{array}{c}\text { SMEs } \\
\text { (D2) }\end{array}$ & $\begin{array}{c}\text { Developed } \\
\text { Countries } \\
\text { (A1) }\end{array}$ & $\begin{array}{c}\text { Developing } \\
\text { Countries } \\
\text { (A2) }\end{array}$ \\
\hline $\begin{array}{c}\text { Strategic routines and } \\
\text { competencies }\end{array}$ & SR & Very high impact & Medium impact & High impact & Medium impact \\
\hline Integrated value chains & SC & Very high impact & High impact & High impact & High impact \\
\hline $\begin{array}{c}\text { Sustainability oriented } \\
\text { transformations }\end{array}$ & ST & Very high impact & Medium impact & Very high impact & Medium impact \\
\hline $\begin{array}{c}\text { Strategic organizational } \\
\text { development }\end{array}$ & OD & High impact & Very high impact & High impact & Very high impact \\
\hline
\end{tabular}

Sustainability oriented transformations are found to be essential drivers strongly influencing large corporations and developed nations to develop dynamic capabilities while having a medium impact on SMEs and in developing nations to encourage them to develop a set of dynamic capabilities $[43,51,53]$.

Although large corporations and developed nations have already started to realize the importance of strategic organizational development as a source to develop dynamic capabilities, it still is a driver having an impact on how successfully organizations can develop dynamic capabilities. With the increasing need for competitive advantage and scarcity of resources, this need for strategic organizational development is vital for SMEs and developing countries, as the developed countries and large organizations usually have better access to resources $[39,41,42,47,53,54,57]$.

\subsection{Corporate Sustainability for Large Corporations and SMEs in Developed and Developing Countries $(R Q-2)$}

Given the difference in strategic objectives, operational constraints, market dynamics, and top management commitment toward achieving sustainability, different drivers have different impacts on large corporations and SMEs in developed and developing countries, as shown in Table 5.

Environmentally-oriented sustainability is found to be a major driver with a very strong influence on large corporations in developed nations to achieve corporate sustainability. It is due to the strong focus of stakeholders on the large companies in the developed nations in transitioning toward environmental-oriented sustainability and the gradual shift in market dynamics requiring businesses to become more environmentally conscious in their operations and practices. As SMEs and developing countries are still catching up with the sustainability agenda, environmental-oriented sustainability has a medium impact on SMEs and developing countries to achieve sustainable development and overall corporate sustainability $[26,33,34,40,43,47]$.

Through sustainable strategic management, large corporations in both developing and developed countries can successfully achieve corporate sustainability, while SMEs have gradually succeeded in making sustainability a part of their strategic objectives and management practices $[38,39,44,50,53]$. 
Table 5. Drivers for corporate sustainability with impact factor.

\begin{tabular}{cccccc}
\hline Drivers & Codes & $\begin{array}{c}\text { Large Corp } \\
\text { (D1) }\end{array}$ & $\begin{array}{c}\text { SMEs } \\
\text { (D2) }\end{array}$ & $\begin{array}{c}\text { Developed } \\
\text { Countries } \\
\text { (A1) }\end{array}$ & $\begin{array}{c}\text { Developing } \\
\text { Countries } \\
\text { (A2) }\end{array}$ \\
\hline $\begin{array}{c}\text { Environmental-oriented } \\
\text { sustainability }\end{array}$ & ENS & Very high impact & Medium impact & Very high impact & Medium impact \\
\hline $\begin{array}{c}\text { Sustainable strategic } \\
\text { management }\end{array}$ & SR & Very high impact & Medium impact & High impact & High impact \\
\hline $\begin{array}{c}\text { Sustainable dynamic } \\
\text { capabilities }\end{array}$ & SDC & Very high impact & Very high impact & Very high impact & Very high impact \\
\hline $\begin{array}{c}\text { Stakeholder-centric } \\
\text { strategic approach }\end{array}$ & SS & Very high impact & Medium impact & Very high impact & High impact \\
\hline $\begin{array}{c}\text { Sustainable supply chain } \\
\text { management }\end{array}$ & SC & Very high impact & Very high impact & Very high impact & Very high impact \\
\hline $\begin{array}{c}\text { Operations excellence } \\
\text { Sustainable R\&D }\end{array}$ & OE & Very high impact & Medium impact & Very high impact & Medium impact \\
\hline $\begin{array}{c}\text { Sustainability-oriented } \\
\text { global business strategy }\end{array}$ & SGS & Very high impact & Medium impact & Very high impact & Medium impact \\
\hline
\end{tabular}

Acquiring sustainable dynamic capabilities is the most important driver to achieve corporate sustainability in both sectors of large corporations and SMEs in developing and developed countries. Sustainable dynamic capabilities have the strongest influence on the success rate of corporate sustainability and the long-term value creation from this transformation as a mode of competitive advantage [12,33,39-41,43,45,47,49,51,52,56,57].

A stakeholder-centric strategic approach is embedded in the business models of large corporations in developed countries, driving corporate sustainability. It is also becoming increasingly important for developing countries and SMEs to adopt this approach to operate sustainably, as it might gradually become a market norm and a norm of practice globally $[33,39,40,44,47,49]$.

Sustainable supply chain management not only delivers efficiency through timely deliveries and value creation but also acts as a very high-impact driver of corporate sustainability in large corporations, SMEs, developing countries, and developed countries to an equal extent. Businesses cannot afford to work in silos anymore and require sustainable raw materials, operations, and lean supply chains as sources of value addition $[52,53,56]$.

Large corporations, specifically in developed countries, are strategically focused on achieving operational excellence through several innovations and sustainability practices, so this approach has become a strong driver to achieve corporate sustainability for these businesses. SMEs and developing nations are also streamlining their operations as more and more regulatory and social pressures are impacting them as well. Hence operational excellence has also become a driver for integrating corporate sustainability for these businesses and countries [40,52].

Innovation lies at the heart of sustainable businesses, as it is primarily driven through research and development projects. Sustainable research and development projects act as very strong influencers for large corporations and developed nations to achieve sustainability goals. As research and development projects are relatively limited in SMEs and developing countries, these segments are currently not experiencing the strongest drive to sustainability through these practices, but still witness the impact on achieving sustained competitive advantage [33,38,40,42].

Large corporations such as multinational enterprises in developed countries have now become global businesses with operations spread across different geographies. Given the different sets of operational, social, environmental, and regulatory requirements, a sustainability-oriented global business strategy is needed to achieve maintenance for 
such businesses. As large corporations usually outsource and employ SMEs and firms in developing countries, becoming a part of this sustainability-oriented global strategy is the only way forward for SMEs and developing companies for competitiveness in the region $[33,44,49]$.

\subsection{Interrelationship between Drivers of Dynamic Capabilities and Corporate Sustainability}

On critically analyzing the drivers of dynamic capability and corporate sustainability, it is found that sustainable strategic management and sustainable supply chain management are the common drivers for achieving corporate sustainability and developing dynamic capabilities, as shown in Figure 12.

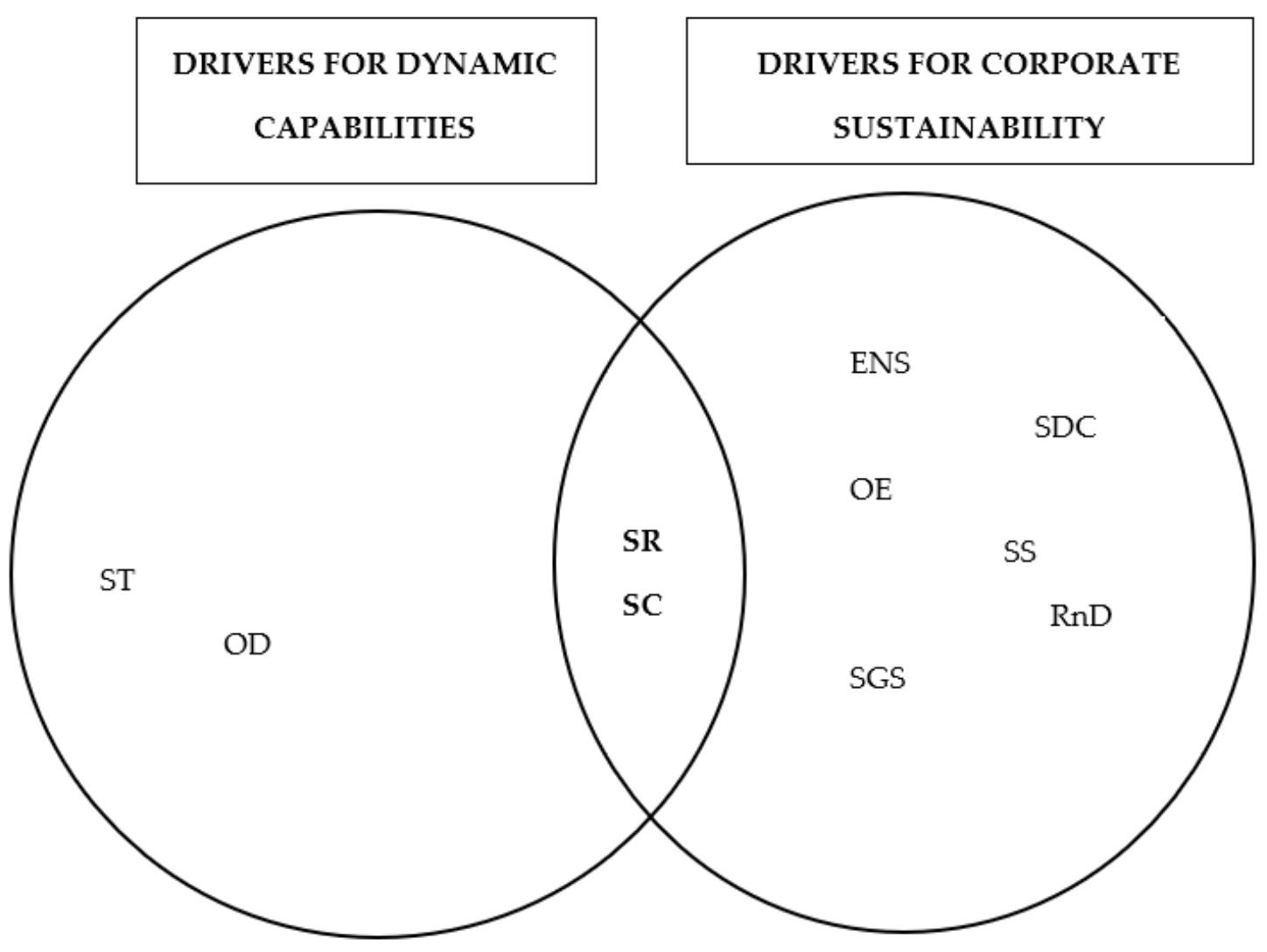

Figure 12. The interrelationship between drivers of dynamic capabilities and corporate sustainability.

This is an important realization for businesses on a journey to achieve sustained competitive advantage. If these businesses focus on deploying sustainable strategic management practices while integrating their value chains for sustainable supply chain management, it will not only enable them to develop new sets of dynamic capabilities but can also help them to achieve corporate sustainability. Since dynamic capabilities are found to deliver competitive advantage, these routines and practices can also ultimately deliver sustained competitive advantage.

Dynamic capabilities are used to achieve a competitive advantage, but over time what is considered dynamic today becomes a market practice in the future and the existing set of dynamic capabilities converts into ordinary and static organizational capabilities [12,33,39-43,45-47,49,51,52,56,57].

The drivers which are found to be common for developing dynamic capabilities and sustainability also demonstrate sensing, seizing, and transformative capabilities for the organization. Based on dynamic capabilities theory, this leads to the understanding that corporate sustainability itself is a dynamic capability. The routines and drivers of corporate sustainability enable businesses to sense the opportunities and threats, seizing the targeted 
opportunities and transforming them according to the market requirements. Through focusing on these common drivers, routines, and micro-foundations, organizations can strategically compete in the changing business landscape.

\section{Conclusions}

During the past 5 years, although there has been an increased research focus on the integrative nature of dynamic capabilities and sustainability, the research agenda of those studies has been very limited and could not present or investigate the detailed aspects of the drivers and routines of dynamic capabilities and corporate sustainability to understand their full impact on business strategies. The majority of past research has focused on sustainability as a standalone operational practice mostly in developed countries, and there is an overwhelming lack of research providing the comparison between the sustainability issues faced in developed and developing countries Thus, this systematic review has analyzed 29 research articles and explained all the routines, micro-foundations, and competencies which can eventually become the drivers for dynamic capabilities and corporate sustainability. No previous study has provided such a detailed overview of routines, practices, and micro-foundations, which ultimately become the DNA of dynamic capabilities and corporate sustainability.

Using the dynamic capabilities theory, this study has introduced a concept of sustainable dynamic capabilities which can be defined as "the set of sustainability-focused capabilities sufficiently dynamic to renew, revise, and adapt according to the requirements of the ever business environment". When an organization develops sustainability-focused dynamic capabilities, corporate sustainability itself becomes a dynamic capability that will then equip businesses to competently sense opportunities and threats, seize the relevant sustainability-oriented opportunities, and mitigate threats through transforming as per the market dynamics. This can become a theoretical extension of Professor David Teece's theory of dynamic capabilities.

To further understand the full impact of sustainable dynamic capabilities and corporate sustainability, based on the propositions, a conceptual framework is presented on the interrelationship of sustainable dynamic capabilities and corporate sustainability having a considerable impact on the sustained competitive advantage for contemporary businesses. Sustainable strategic management and sustainable supply chain management are found to be the common themes to drive both corporate sustainability and dynamic capabilities. Companies should enhance their focus on sustainable supply chain management and sustainable strategic management to outperform their competitors.

This research has a theoretical implication on the extension of the dynamic capabilities theory in conjunction with the corporate sustainability agenda. For future research, empirical studies should be carried out to verify the proposed conceptual framework. Practitioners, managers, and executives can use this conceptual model to understand the true impact of dynamic capability and sustainability on competitive advantage. They can have clarity on the drivers of dynamic capabilities and sustainability and can narrow down their efforts to focus on the relevant and effective routines to develop dynamic capabilities and achieve corporate sustainability successfully while bringing about competitive advantage. Given the nature of the research problem, this study has only employed qualitative methods, hence quantitative data are lacking. Future research can focus on validating this conceptual model using broader empirical data, ideally from both developed and developing countries. Quantitative studies based on the data received from case studies and surveys can provide the statistical output to quantify the impact of sustainable dynamic capabilities and corporate sustainability on sustained competitive advantage.

Author Contributions: N.B.: Conceptualization, Methodology, Analysis, Investigation and Original Writing; R.C. and K.-C.C.: Review and Editing. All authors have read and agreed to the published version of the manuscript.

Funding: This research received no external funding.

Institutional Review Board Statement: Not applicable. 
Informed Consent Statement: Not applicable.

Conflicts of Interest: The authors declare no conflict of interest.

\section{References}

1. Oertwig, N.; Galeitzke, M.; Schmieg, H.G.; Kohl, H.; Jochem, R.; Orth, R.; Knothe, T. Integration of Sustainability into the Corporate Strategy. In Sustainable Manufacturing, Challenges, Solutions and Implementation Perspectives; Springer: Berlin/Heidelberg, Germany, 2017; pp. 175-200. [CrossRef]

2. Serafeim, G. Making Sustainability Count. Harvard Business Review. September-October 2020, pp. 1-16. Available online: https:/ /hbr.org/2020/09/social-impact-efforts-that-create-real-value\#social-impact-efforts-that-create-real-value (accessed on 15 July 2021).

3. Cui, Y.; Jiao, H. Dynamic capabilities, strategic stakeholder alliances and sustainable competitive advantage: Evidence from China. Corp. Gov. 2011, 11, 386-398. [CrossRef]

4. Amui, L.B.L.; Jabbour, C.J.C.; Jabbour, A.B.L.S.; Kannan, D. Sustainability as a dynamic organizational capability: A systematic review and a future agenda toward a sustainable transition. J. Clean. Prod. 2017, 142, 308-322. [CrossRef]

5. Alonso, A.D.; Kok, S. A resource-based view and dynamic capabilities approach in the context of a region's international attractiveness: The recent case of Western Australia. Local Econ. 2018, 33, 307-328. [CrossRef]

6. Markard, J.; Raven, R.; Truffer, B. Sustainability transitions: An emerging field of research and its prospects. Res. Policy 2012, 41, 955-967. [CrossRef]

7. Lozano, R.; Carpenter, A.; Huisingh, D. A review of theories of the firm and their contributions to Corporate Sustainability. J. Clean. Prod. 2015, 106, 430-442. [CrossRef]

8. Wu, Q. Developing Dynamic Capabilities for Corporate Sustainability: The Role of Knowledge Transfer between Supply Chain Partners. Ph.D. Thesis, University of Bedfordshire, Luton, UK, 2017.

9. Teece, D.J. Business models and dynamic capabilities. Long Range Plan. 2018, 51, 40-49. [CrossRef]

10. Bocken, N.M.P.; Short, S.W.; Rana, P.; Evans, S. A literature and practice review to develop sustainable business model archetypes. J. Clean. Prod. 2013, 65, 42-56. [CrossRef]

11. Geissdoerfer, M.; Vladimirova, D.; Evans, S. Sustainable business model innovation: A review. J. Clean. Prod. 2018, 198, 401-416. [CrossRef]

12. Buzzao, G.; Rizzi, F. On the conceptualization and measurement of dynamic capabilities for sustainability: Building theory through a systematic literature review. Bus. Strategy Environ. 2021, 30, 135-175. [CrossRef]

13. Shahbazpour, M.; Seidel, R.H. Using Sustainability for Competitive Advantage. In Proceedings of the LCE 13th CIRP International Conference on Life Cycle Engineering, Leuven, Belgium, 31 May-2 June 2006; pp. 287-292.

14. Porter, M.E.; Kramer, M.R. Strategy and Society: The Link between Competitive Advantage and Corporate Social Responsibility. Harvard Business Review. December 2006, pp. 78-85. Available online: https:/ /hbr.org/2006/12/strategy-and-society-the-linkbetween-competitive-advantage-and-corporate-social-responsibility (accessed on 15 July 2021).

15. Hart, S.L.; Dowell, G. A natural-resource-based view of the firm: Fifteen years after. J. Manag. 2011, 37, 1464-1479.

16. Nzyoka, J.M.; Kamaku, P.; Munyao, J. Effect of Organizational capabilities on sustainable competitive advantage in audit firms: A case study of Deloitte Limited. J. Bus. Strateg. Manag. 2017, 2, 50-77. [CrossRef]

17. Berns, M.; Townend, A.; Khayat, Z.; Balagopal, B.; Reeves, M.; Hopkins, S.M.; Kruschwitz, N. Sustainability and Competitive Advantage. MIT Sloan Manag. Rev. 2009, 51, 19-26.

18. Roghe, F.; Toma, A.; Kilmann, J.; Dickie, R.; Strack, R. Organizational Capabilities Matter. BCG Henderson Institute, 2012. Available online: https:/ / www.bcg.com/publications/2012/leadership-engagement-culture-organizational-capabilities-matter. aspx (accessed on 15 July 2021).

19. Barreto, I. Dynamic capabilities: A review of past research and an agenda for the future. J. Manag. 2010, 36, 256-280. [CrossRef]

20. Helfat, C.E.; Winter, S.G. Untangling Dynamic and Operational Capabilities: Strategy for the (N)ever-Changing World. Strateg. Manag. J. 2011, 32, 1243-1250. [CrossRef]

21. Beske, P. Dynamic capabilities and sustainable supply chain Management. Int. J. Phys. Distrib. Logist. Manag. 2012, 42, 372-387. [CrossRef]

22. Winter, S.G. Understanding dynamic capabilities. Strateg. Manag. J. 2003, 24, 991-995. [CrossRef]

23. Teece, D.J. Explicating dynamic capabilities: The nature and micro foundations of (sustainable) enterprise performance. Strateg. Manag. J. 2007, 28, 1319-1350. [CrossRef]

24. Jiao, H.; Wei, J.; Cui, Y. An empirical study on paths to develop dynamic capabilities: From the perspectives of entrepreneurial orientation and organizational learning. Front. Bus. Res. China 2010, 4, 47-72. [CrossRef]

25. Eisenhardt, K.M.; Martin, J.A. Dynamic capabilities: What are they? Strateg. Manag. J. 2000, 21, 1105-1121. [CrossRef]

26. Rashid, N.; Jabar, J.; Yahya, S.; Shami, S. Dynamic Eco Innovation Practices: A Systematic Review of State of the Art and Future Direction for Eco Innovation Study. Asian Soc. Sci. 2015, 11, 8-21. [CrossRef]

27. Junior, L.M.; Filho, G.M. Production planning and control for remanufacturing: Literature review and analysis. Prod. Plan. Control 2012, 23, 419-435. [CrossRef] 
28. Jabbour, C.J.C. Environmental training in organizations: From a literature review to a framework for future research. Resour. Conversat. Recycl. 2013, 74, 144-155. [CrossRef]

29. Govindan, K.; Soleimani, H.; Kannan, D. Reverse logistics and closed-loop supply chain: A comprehensive review to explore the future. Eur. J. Oper. Res. 2015, 240, 603-626. [CrossRef]

30. Dubey, R.; Gunasekaran, A.; Childe, S.J.; Papadopoulos, T.; Wamba, S.F. World class sustainable supply chain management: Critical review and further research directions. Int. J. Logist. Manag. 2017, 28, 332-362. [CrossRef]

31. Costa, L.B.M.; Filho, G.M. Lean healthcare: Review, classification and analysis of literature. Prod. Plan. Control 2016, $27,823-836$. [CrossRef]

32. Fahimnia, B.; Sarkis, J.; Davarzani, H. Green supply chain management: A review and bibliometric analysis. Int. J. Prod. Econ. 2015, 162, 101-114. [CrossRef]

33. Crittenden, V.L.; Crittenden, W.F.; Ferrell, L.K.; Ferrell, O.C.; Pinney, C.C. Market-oriented sustainability: A conceptual framework and propositions. J. Acad. Mark. Sci. 2011, 39, 71-85. [CrossRef]

34. Hofmann, K.H.; Theyel, G.; Wood, C.H. Identifying Firm Capabilities as Drivers of Environmental Management and Sustainability Practices-Evidence from Small and Medium-Sized Manufacturers. Bus. Strategy Environ. 2012, 21, 530-545. [CrossRef]

35. Wu, Q.; He, Q.; Duan, Y. Explicating dynamic capabilities for corporate sustainability. EuroMed J. Bus. 2013, 8, 255-272. [CrossRef]

36. Borland, H.; Ambrosini, V.; Lindgreen, A.; Vanhamme, J. Building Theory at the Intersection of Ecological Sustainability and Strategic Management. J. Bus. Ethics 2016, 135, 293-307. [CrossRef]

37. Dangelico, R.M.; Pujari, D.; Pontrandolfo, P. Green Product Innovation in Manufacturing Firms: A Sustainability-Oriented Dynamic Capability Perspective. Bus. Strategy Environ. 2017, 26, 490-506. [CrossRef]

38. Kiefer, C.P.; Gonzalez, P.D.R.; Carrillo-Hermosilla, J. Drivers and barriers of eco-innovation types for sustainable transitions: A quantitative perspective. Bus. Strategy Environ. 2018, 28, 155-172. [CrossRef]

39. Mousavi, S.; Bossink, B.; Vliet, M.V. Dynamic capabilities and organizational routines for managing innovation towards sustainability. J. Clean. Prod. 2018, 203, 224-239. [CrossRef]

40. Ullern, E.F.; Ramstad, L.S. How manufacturing companies can utilize innovation test-centers in facilitating environmental sustainability. In Proceedings of the ISPIM Innovation Conference-Innovation, The Name of The Game, Stockholm, Sweden, 17-18 June 2018.

41. Inigo, E.A.; Albareda, L. Sustainability oriented innovation dynamics: Levels of dynamic capabilities and their path-dependent and self-reinforcing logics. Technol. Forecast. Soc. Chang. 2019, 139, 334-351. [CrossRef]

42. Li, L.; Li, G.; Tsai, F.S.; Lee, H.Y.; Lee, C.H. The Effects of Corporate Social Responsibility on Service Innovation Performance: The Role of Dynamic Capability for Sustainability. Sustainability 2019, 11, 2739. [CrossRef]

43. Durge, V.C.; Sangle, S. Technology, sustainable development, and corporate growth-Striking a balance. World Rev. Sci. Technol. Sustain. Dev. 2020, 16, 105-121. [CrossRef]

44. Chakrabarty, S.; Wang, L. The Long-Term Sustenance of Sustainability Practices in MNCs: A Dynamic Capabilities Perspective of the Role of R\&D and Internationalization. J. Bus. Ethics 2012, 110, 205-217.

45. Zhang, Y.; Sun, J.; Yang, Z.; Li, S. Organizational Learning and Green Innovation: Does Environmental Proactivity Matter? Sustainability 2018, 10, 3737. [CrossRef]

46. Bocken, N.M.P.; Geradts, T.H.J. Barriers and drivers to sustainable business model innovation: Organization design and dynamic capabilities. Long Range Plan. 2020, 53, 101950. [CrossRef]

47. Wu, Q.; He, Q.; Duan, Y.; O’Regan, N. Implementing Dynamic Capabilities for Corporate Strategic Change Toward Sustainability. Strateg. Chang. 2012, 21, 231-247. [CrossRef]

48. Beske, P.; Land, A.; Seuring, S. Sustainable supply chain management practices and dynamic capabilities in the food industry: A critical analysis of the literature. Int. J. Prod. Econ. 2014, 152, 131-143. [CrossRef]

49. Albareda, L.; Inigo, E.A. A capability-based view of sustainability-oriented innovation: An exploratory study. Acad. Manag. Proc. 2016, 2016, 11336. [CrossRef]

50. Ciasullo, M.V.; Montera, R.; Cucari, N.; Polese, F. How an international ambidexterity strategy can address the paradox perspective on corporate sustainability: Evidence from Chinese emerging market multinationals. Bus. Strategy Environ. 2020, 29, 2110-2129. [CrossRef]

51. Shang, H.; Chen, R.; Li, Z. Dynamic sustainability capabilities and corporate sustainability performance: The mediating effect of resource management capabilities. Sustain. Dev. 2019, 28, 595-612. [CrossRef]

52. Suh, C.J.; Lee, I.T. An Empirical Study on the Manufacturing Firm's Strategic Choice for Sustainability in SMEs. Sustainability 2018, 10, 572. [CrossRef]

53. Kumar, G.; Subramanian, N.; Arputham, R.M. Missing link between sustainability collaborative strategy and supply chain performance: Role of dynamic capability. Int. J. Prod. Econ. 2018, 203, 96-109. [CrossRef]

54. Cezarino, L.O.; Alves, M.F.R.; Caldana, A.C.F.; Liboni, L.B. Dynamic Capabilities for Sustainability: Revealing the Systematic Key Factors. Syst. Pract. Action Res. 2019, 32, 93-112. [CrossRef]

55. Khan, O.; Daddi, T.; Iraldo, F. Microfoundations of dynamic capabilities: Insights from circular economy business cases. Bus. Strategy Environ. 2019, 29, 1479-1493. [CrossRef]

56. Medina-Serrano, R.; Gonzalez, R.; Gasco, J.; Llopis, J. Collaborative and sustainable supply chain practices: A case study. J. Enterprising Communities People Places Glob. Econ. 2020, 14, 3-21. [CrossRef] 
57. Maksimov, V.; Wang, S.L.; Yan, S. Global connectedness and dynamic green capabilities in MNEs. J. Int. Bus. Stud. 2019, 1-18. [CrossRef]

58. Zollo, M.; Bettinazzi, E.L.M.; Neumann, K.; Snoeren, P. Toward a comprehensive model of organizational evolution: Dynamic capabilities for innovation and adaptation of the enterprise model. Glob. Strategy J. 2016, 6, 225-244. [CrossRef] 